
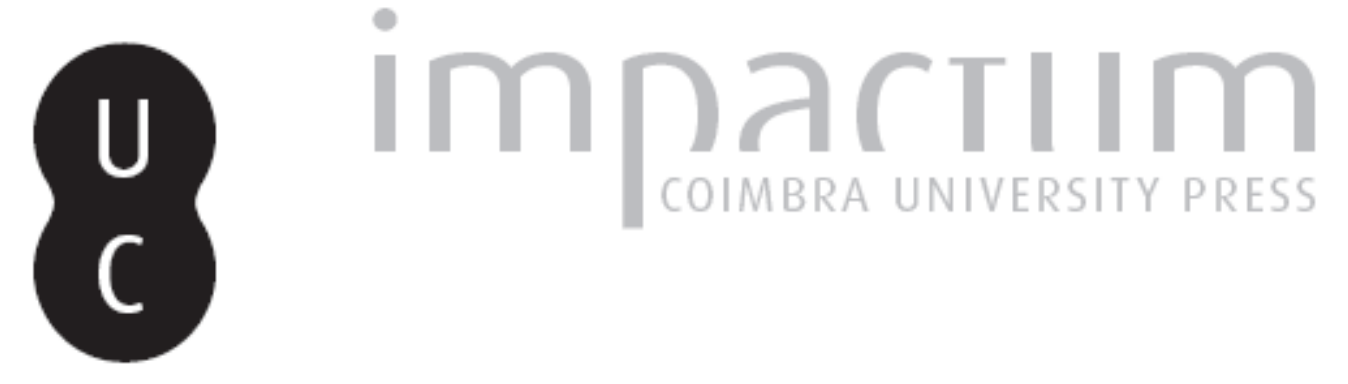

\title{
Portugueses no processo histórico da fundação da Universidade de Salamanca
}

\author{
Autor(es): $\quad$ Antunes, José
}

Publicado por: Imprensa da Universidade de Coimbra

URL persistente:

http://hdl.handle.net/10316.2/42878

DOI:

https://doi.org/10.14195/2183-8925_12_2

Accessed : $\quad$ 26-Apr-2023 15:48:23

A navegação consulta e descarregamento dos títulos inseridos nas Bibliotecas Digitais UC Digitalis, UC Pombalina e UC Impactum, pressupõem a aceitação plena e sem reservas dos Termos e Condições de Uso destas Bibliotecas Digitais, disponíveis em https://digitalis.uc.pt/pt-pt/termos.

Conforme exposto nos referidos Termos e Condições de Uso, o descarregamento de títulos de acesso restrito requer uma licença válida de autorização devendo o utilizador aceder ao(s) documento(s) a partir de um endereço de IP da instituição detentora da supramencionada licença.

Ao utilizador é apenas permitido o descarregamento para uso pessoal, pelo que o emprego do(s) título(s) descarregado(s) para outro fim, designadamente comercial, carece de autorização do respetivo autor ou editor da obra.

Na medida em que todas as obras da UC Digitalis se encontram protegidas pelo Código do Direito de Autor e Direitos Conexos e demais legislação aplicável, toda a cópia, parcial ou total, deste documento, nos casos em que é legalmente admitida, deverá conter ou fazer-se acompanhar por este aviso.

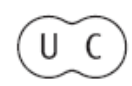




\section{UNIVERSIDADE}

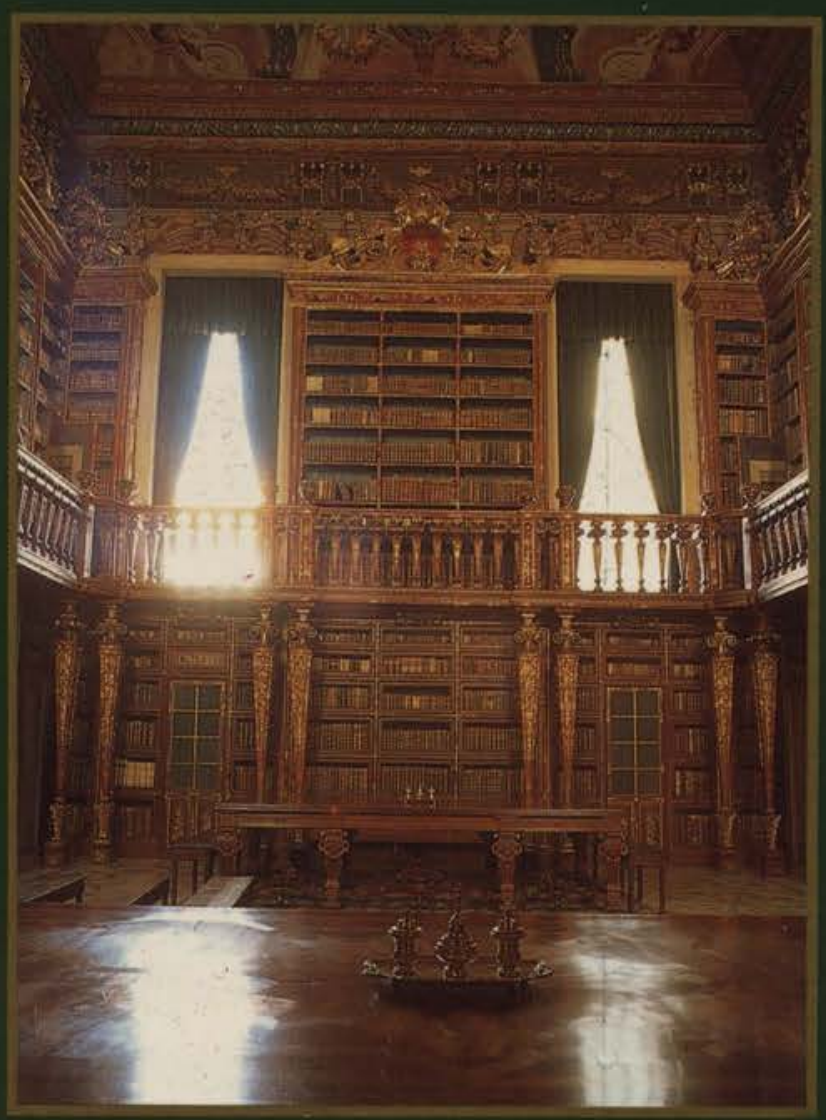

INSTITUTO DE HISTORIA E TEORIA DAS IDEIAS FACULDADE DE LETRAS 


\section{PORTUGUESES NO PROCESSO HISTÓRICO DA FUNDAÇÃO DA UNIVERSIDADE DE SALAMANCA **}

\section{A propósito de Fernando Joanes de Portocarreiro, Miguel Peres e Pedro Moniz}

Segundo Lucas de Tuy, Afonso IX (1171-1230), rei de Leão, firmada a paz com o seu filho Fernando, rei de Castela, e dominados alguns rebeldes do reino, congregou um grande exército contra os sarracenos. E depois de arrasar, a ferro e fogo, tudo à volta de Cáceres, como árvores, vinhas e searas, regressou novamente ao seu reino.

Então, seguindo um salutar conselho, convocou peritíssimos mestres nas Sagradas Escrituras e fundou as Escolas em Salamanca.

E o Tudense, tendo presente o I Livro dos Macabeus ( $\left.{ }^{1}\right)$ escreve, em género de sentença: e desde aquele dia a felicidade da vitória mais se firmava nas suas mãos - et ab illa die magis est victoria salus in manu eius (2). O que tanto se pode interpretar no sentido bíblico de que a fundação dos estudos seria o caminho mais seguro para a felicidade do povo e a verdadeira vitória que este necessitava e que mais

* Faculdade de Letras da Universidade de Coimbra.

** Na elaboração deste trabalho deparámos com várias e não pequenas dificuldades por não termos fácil acesso a algumas obras e a certos documentos que era imperioso consultar. Aos Professores Doutores António Garcia y Garcia, José Mattoso, José Geraldes Freire, José Marques e Luís Reis Torgal, testemunhamos o nosso mais vivo agradecimento, quer pela cedência temporária de algumas dessas obras e documentação, quer pela atenção que sempre nos dispensaram.

(1) I Macab. 3,6: et directa est salus in manu eius (e a salvação do povo firmava-se em suas mãos).

(2) Para o texto de Afonso IX, ver Lucas Tudensis, Chronicon Mundi, Era 1255. Ed. «Hispania illustrata», tomo IV, Francofurti, 1608, p. 113. Transcrito em Vicente Beltrán de Heredia, "Los orígenes de la Universidad de Salamanca», in Acta Salmanticensia iussu senatus Universitatis edita, tomo I, n ${ }^{\circ} \mathrm{I}$, Universidad de Salamanca, 1953 e reeditado em 1983, p. 20 e ainda pelo mesmo autor em Cartulario de la Universidad de Salamanca (1218-1600) I, Universidade de Salamanca, 1970, pp. 596-597. 
o enriquecia $\left({ }^{3}\right)$, como no sentido de que um tão notável acontecimento se viria a repercutir favoravelmente nas suas conquistas.

Mas o que mais importa registar, de momento, é que através desta preciosa informação do bispo de Tuy, é posssível determinar a data da feliz fundação da Universidade de Salamanca ou da transformação da Escola catedralícia em Estudo Geral que tem de se situar entre o levantamento do referido cerco de Cáceres ocorrido em Agosto de 1218 e o conflito com o rei de Portugal que terminou com o tratado de paz em 1219. Porque, logo a seguir, no mesmo documento, o Tudense refere que o rei de Leão, sentindo-se ofendido pelo monarca português, cercou e conquistou o castelo de S. Estêvão de Chaves celebrando-se posteriormente a paz, que, como se sabe, teve lugar precisamente em Baronal, a 13 de Junho de 1219 (4).

Mas se é verdade que desde este período até à morte, Afonso IX jamais deixou de favorecer e proteger as suas Escolas, o filho que lhe sucedeu, Fernando III (1192-1252), então rei de Castela (1217) e de Leão (1230), não menos cuidou da sua organização e regulamentação, o que constitui uma segunda etapa importante em todo o processo da história da vetusta instituição.

A questão enunciada no título deste trabalho surgiu-nos, precisamente, ao relermos um dos privilégios concedidos por este monarca ao Estudo salmanticense, em 6 de Abril de 1243 e que na feliz expressão do historiador Vicente de la Fuente, constitui o "primeiro estatuto da Universidade de Salamanca" e o "primeiro documento universitário de Espanha", "tão digno de estima e de respeito que em 1856 foi colocado em letras bem visíveis, num grande marco dourado, na Real Capela da mesma Universidade» (5).

Também Demetrio Mansilla Reoyo regista a importância desta data na história da Universidade de Salamanca visto que a primeira fun-

(3) Não muito longe deste sentido, embora mais tarde (1256-1264), mas também sobre os Estudos de Salamanca, diria Afonso X, através do título XXXI das Siete Partidas: É porque de los homes sabios, los homes e las tierras e los reinos se aprovechan e se guardan e se guian por el consejo de ellos, por ende queremos en la fin de esta Partida fablar de los Estudios...

(4) De facto, as tréguas foram estabelecidas durante vinte anos, entre Afonso II de Portugal e Afonso IX de Leão - treugas etiam XX annorum inter se firmaverunt. Cf. J. Conzalez, Afonso IX, II, Madrid, Instituto Jeronimo Zurita, 1944, doc. 373, p. 488. Cf. Maria Teresa N. Veloso, D. Afonso II-Relaçôes de Portugal com a Santa Sé durante o seu reinado (Tese de doutoramento), Coimbra, 1988, pp. 245, 267,270 e 320 .

(5) Referência em D. Vicente de La Fuente, Historia de las Universidades, Colegios y demas Establecimientos de Enseñanza en España, Tomo I, Madrid, 1884, p. 89; cf. igualmente Henrique Esperabé Arteaga, Historia de la Universidad de Salamanca, Tomo I - La Universidad de Salamanca y los Reyes, Salamanca, 1914, pp. 19 e 436. 
dação de 1218 não teve o resultado que se esperava. Então, segundo a interpretação deste autor, Fernando III sentiu-se obrigado a dar vida à Universidade mediante um novo documento, que pode considerar-se como o primeiro "estatuto universitário», não só de Salamanca, mas da própria Espanha. Chama-lhe inclusivamente «acta da fundação» firmada em Valladolid, a 6 de Abril de 1243, na qual o Rei Santo, reconhecendo a necessidade da ciência, para o seu reino, procedeu à fundação das Escolas de Salamanca ( $\left.{ }^{6}\right)$.

Outras fases históricas, não menos notáveis, se seguiram em todo este processo inicial. Como a Carta Magna, concedida por Afonso X, o Sábio, em 8 de Maio de 1254, a pedido dos «escolares do Estudo da Universidade», que regulamentava as suas cátedras e garantia os salários e que, depois da fundação, constitui o mais célebre diploma e «O mais assinalado favor» régio que a mesma instituição recebeu ( $\left.{ }^{7}\right)$. Assim como a bula confirmatória Inter ea quae placita em resposta à petição do mesmo monarca e que lhe foi dirigida a 6 de Abril de 1255, pelo pontífice Alexandre IV, dispensando ao Estudo Geral diversos privilégios que asseguravam a sua continuidade $\left(^{8}\right)$.

Porém, de momento, e para o nosso objectivo, o que mais nos interessa analisar é o referido privilégio de 1243 de Fernando III, onde, provavelmente, são também mencionados portugueses.

Transcrito e analisado por vários historiadores $\left({ }^{9}\right)$ o documento reza assim:

(6) Demetrio Mansilla Reoyo, Iglesia castellana-leonesa y Curia Romana en los tiempos del Rey Don Fernando - Estudio Documental sacado de los Registros Vaticanos, Madrid, 1945, p. 263.

(7) Expressões de Vicente Beltrán de Heredia, Los origenes de la Universidad de Salamanca, cit., p. 21, onde se analisa todo o documento que vem transcrito integralmente também na sua obra Cartulario de la Universidad de Salamanca (1218-1600), Universidad de Salamanca, 1970, pp. 604-606; ver ainda Henrique Esperabé Arteaga, ob. cit., Tomo I, pp. 21-23. Cf. Antonio García y García, Los dificiles inicios (siglos XIII-XIV) - Separata de La Universidad de Salamanca, 1: Historia y projecciones, Salamanca, 1989, pp. 18 e 19, onde se focam os pontos essenciais destes documentos.

(8) Cf. doc. em Vicente Beltrán de Heredia, Bulario de la Universidad de Salamanca, (1219-1549) - I, 1966, pp. 319-320; Antonio García y García, ob. cit., p. 18.

(9) Como, por exemplo, em Alejandro Vidal y Diaz, Memoria Historica de la Universidad de Salamanca, Salamanca, 1869, p. 15; Vicente de La Fuente, ob. cit., p. 89; C.M. Ajo G. y Sáinz de Zuñiga, Historia de las Universidades Hispanicas Origenes y desarollo desde su aparición hasta nuestros dias. I. Medievo y Renacimiento Universitario, Madrid, 1957, pp. 221-222 y 436; publicado em parte e comentado por Vicente Beltrán de Heredia, Los origenes de la Universidad de Salamanca - Historia de la Universidad, Tomo I, núm. 1, Universidad de Salamanca, 1953, p. 11, trabalho posteriormente repetido nas Acta Salmanticensia iussv senatus Vniversitatis Edita-Historia de la Universidad, Tomo I, num. 1, Universidad de Salamanca, 1983. Veja-se sobretudo Joaquim Veríssimo Serrão, Portugueses no Estudo de Salamanca - I (1250-1550), Lisboa, 1962, pp. 20-22, onde igualmente se trans- 
Valladolid, 6 de Abril de 1243

«Conoscida cosa sea a todos cuantos esta carta virem como jo Don Fernando por la gracia de Dios Rey de Castiella e de Toledo de Leon de Gallicia e de Cordova porque entiendo que es pro de myo Reyno e de mi terra otorgo e mando que aya escuelas en Salamanca e mando que todos aquellos que hi quisieren venir e leer que vengan seguramiente e jo recibo en mi comienda e en myo defendimiento á los maestros e a los escolares que hy vinieren e a sos homes e a sus cosas quantas que hy troxieren e quiero e mando que aquellas costumbres e aquellos fueros que ovieron los escolares en Salamanca en tiempo de myo padre quando establecido hy las escuelas tambien en casas como en las otras cosas que essas costumbres e essos fueros ayan e nenguno que les fiziesse tuerto nin fuerza nin demás á ellos nin a sos omes nin a sua cosas avrie ni ira e pecharme ye en coto mill marbs e a ellos el danno duplado. Otrosi mando que los escolares bivan en paz e cuerdamiente de guisa que non fagan tuerto nin demas a los de la villa e toda cosa que caezca de contienda o de pelea entre los escolares o entre los de la villa e los escolares que estos son nombrados en esta mi carta lo ayan de veer e de enderezar. El obispo de Salamanca e el dean e el prior de los predicadores, e el guardiano de los descalços e don Rodrigo e Pedro Guigelmo e Garci Gomez e Pedro Vellido e Ferrand iohannes de porto carrero e Pedro Munniz calonigo de leon e Miguel $\mathrm{Pz}$ calonigo de Lamego en los escolares e los de la villa mando que esten por lo que estos mandaren. Fta carta ap'd Vallectum Reg xp VI die Aprilis Era M-CC-LXXX prima».

Da análise da presente escritura podemos destacar os seguintes pontos:

1. Fernando III outorga e manda que haja Escolas em Salamanca.

2. Cuida da protecção e salvaguarda dos mestres e escolares, assim como dos seus haveres.

3. Reconhece os costumes, usos e foros já concedidos por seu pai, Afonso IX, aos escolares, recordando-o como verdadeiro fundador das Escolas Salmanticenses.

creve na íntegra o documento. E uma obra de alto valor para a história da cultura, sobretudo no âmbito das relações culturais entre Espanha e Portugal. Cf. A.M. Rodriguez Cruz, Colección documental. Selección de algunos, de los documentos mas importantes de la historia en la Universidad de Salamanca y de su proyección americana, Salamanca, 1977, n. 1, p. 13.

Porém, o texto que seguimos, vem reproduzido em Vicente La Fuente, ob. cit., p. 89. Comparado com a leitura de outros autores, como por exemplo Julio González, Reinado y diplomas de Fernando III, T. III - Diplomas (1233-1253), Cordoba, 1986 , pp. 261-262 e dos autores acima citados apresenta algumas variantes insignificantes que em nada afectam a nossa questão. Veja-se nesta obra a importante bibliografia que encabeça o documento, p. 261. 
4. Determina uma penalização de mil maravedis para o tesouro real e de dois mil para os prejudicados sobre todos aqueles que atentarem contra eles.

5. Apela à paz e à boa harmonia com os vizinhos e vice-versa.

6. Cria um tribunal próprio para julgar as contendas que porventura surjam entre os escolares ou entre estes e os da vila, constituído por elementos tanto do reino de Leão e Castela, como de Portugal, nomeados pessoalmente pelo monarca $\left({ }^{10}\right)$.

Deste tribunal ou junta de justiça universitária, faria parte, como o próprio documento claramente regista, Miguel Perez ou Pires, cónego de Lamego, apontado, até aqui, como o primeiro português na história da Escola de Salamanca e já devidamente referenciado, por vários historiadores, com destaque para Vicente de La Fuente e Joaquim Veríssimo Serrão.

Se era ou não catedrático da nova Universidade, é uma hipótese ou simples conjectura encarada também por alguns autores no sentido de que não seria crível que Fernando III fosse nomear para a referida Junta cónegos forasteiros, ausentes das suas Igrejas, por motivo de estudos, uma vez que a todo o tempo teriam de regressar à sua residência. E se estavam ausentes das dioceses de origem, não se vislumbra outra causa de tal ausência senão o desempenho das suas respectivas cátedras (11).

Mas Miguel Peres não é o primeiro e o único português referido no presente diploma.

Ferrand iohanes de porto carrero, mencionado no mesmo documento, do monarca castelhano, é também português.

Trata-se de Fernão Joanes de Portocarreiro, futuro deão de Braga, que nos surge, em cada passo, e em várias escrituras, não apenas relacionadas com Fernando III, mas sobretudo com Pedro Hispano e Afonso

(10) Cf. Vicente de La Fuente, ob. cit., pp. 90-91; C.M. Ajo G. y Sáinz Zuñiga, ob. cit., pp. 221-222.

(11) Opinião emitida por Vicente de La Fuente, ob. cit., p. 90. Joaquim Veríssimo Serrão, ob. cit., pp. 21-22, pronunciando-se sobre esta documentação comenta que a seguir-se este critério todos os nomes indicados poderiam ser mestres do nascente Estudo, o que tornaria difícil de aceitação uma tal hipótese. E Antonio García y García, Proyección de la canonistica portuguesa medieval en España - Separata de Presença de Portugal no Mundo, Lisboa, Academia Portuguesa de História, 1982, p. 32, escreve: «Já em 1243 aparece um certo Miguel Pires, cónego de Lamego, nomeado pelo Rei Fernando III para formar parte de um tribunal encarregado de dirimir as contendas entre os Universitários e o município Salmantino. Não sabemos se estudou ou ensinava em Salamanca se bem que parece tratar-se, em todo o caso, de uma pessoa que se impunha em Direito". Ora se isto se pode aplicar a Miguel Pires, com não menos razão se poderá dizer de Fernando Joanes de Portocarreiro que se se identificar com o chantre e mais tarde deão de Braga, deixou em testamento a um sobrinho os seus livros de Direito (nota 19), o que insinua já senão uma formação, pelo menos uma certa propensão jurídica. 
III ou entre este e Afonso X de Castela, para além de figurar em muitas outras, mas estas de carácter mais pessoal.

A identificação é certa. Não apenas por ser pouco verosímil dar-se assim, logo, uma coincidência tão perfeita, e numa mesma altura, de existirem dois clérigos (um em Castela e outro em Portugal) com o mesmo nome, formado por quatro palavras iguais e exactamente com um mesmo apelido tão pouco vulgar. Mas precisamente porque compulsando toda a documentação impressa de Fernão Joanes de Portocarreiro este acto da concessão do precioso privilégio, de 6 de Abril de 1243 , se enquadra, perfeitamente, não só no âmbito da sua formação jurídica, mas sobretudo na lógica do seu itinerário, quer em Castela, como em Portugal.

O problema não nos parece de somenos importância tanto mais que pode ajudar a conhecer melhor o intercâmbio e as relações culturais entre Portugal e os restantes reinos da Península Ibérica do século XIII e, mais concretamente, a acção de alguns portugueses cultos, no processo da fundação da Universidade Salmanticense. Daí que esta intervenção constituía, de certo modo, a melhor e a mais natural preparação para a criação da futura Universidade portuguesa. Julgamos, por isso, que este intercâmbio é digno de nota. Até porque, posteriormente, a Universidade em Portugal veio a receber, por sua vez, uma profunda influência e presença através de muitos mestres salmanticenses, ao longo da sua existência. E, além disso, a participação destes portugueses na vizinha instituição universitária de Salamanca pode até mostrar que o nosso país teve, desde cedo, a possibilidade de fundar uma universidade e torna necessário explicar porque não o fez antes de 1290 . Certamente porque as difíceis relações entre a Coroa e a Santa Sé, durante todo o período, sobretudo de 1220 a 1280 (que abrangeu os reinados de D. Sancho II e D. Afonso III), o não permitiram ou constituíram o maior obstáculo à sua fundação.

De facto, nunca será demasiado acentuar que o século XIII foi, para Portugal, um período culturalmente fecundo, tanto no Direito, que teve os seus mais altos expoentes em Mestre Vicente e Mestre João de Deus, professores da Universidade de Bolonha, como na filosofia e na medicina, em que Pedro Hispano, antigo aluno da Universidade de Paris foi o seu mais célebre representante (12).

(12) Sem esquecer muitos outros estudiosos e dos mais diferentes países é um facto reconhecido por historiadores da própria nação vizinha. Veja-se, por exemplo, Vicente Beltrán de Heredia, Cartulario de la Universidad de Salamanca, cit., a propósito da canonística, p. 98: «El sector portugués puede competir durante aquel siglo con el castellano en materias canónicas, y tal vez le aventaja”. E recorde-se o valioso instrumento de trabalho que é a obra de Antonio García y García, Estudios sobre la canonistica portuguesa medieval, Madrid, 1976. Como é óbvio, não nos move na presente questão qualquer sentimento de patriotismo, mas tão só confirmar, uma vez mais, $a$ inexistência de fronteiraৎ culturais entre os reinos da Península, em plena Idade Média. 


\section{Da família dos Portocarreiros}

Neste contexto, as considerações que se seguem pretendem oferecer alguns elementos essenciais para melhor se compreender não só a justeza da questão, mas também para confirmar a identificação de Ferrand iohanes de porto carrero, nomeado para a Junta Universitária de Justiça, dos Estudos de Salamanca, com Fernão Joanes de Portocarreiro, deão de Braga.

Isto é, com o mesmo personagem que no reinado de D. Sancho II (1223-1248) passou a Castela. Que pela documentação compulsada, tanto o encontramos como notário e procurador do rei castelhano, Afonso X, o Sábio, como no séquito da corte de D. Afonso III de Portugal. E se não andou por Lião ou Viterbo, na Cúria Pontifícia, dificilmente se explica por que motivo aparece designado como capelão do cardeal-diácono Octaviano Ubaldini e até do próprio papa Alexandre IV. Porto, Braga, Valladolid, Salamanca, Lião, Viterbo, Guimarães, Orense, Santarém, S. Pedro do Sul, Vimieiro, Alenquer, Sevilha, Leão, Lisboa, Beja, Tavira, Burgos, etc., são locais que lhe são familiares, ou porque se relacionam com os seus interesses ou porque, de algum modo, aparecem vinculados à sua própria passagem. Participou nas Cortes de Guimarães, em 1250, conjuntamente com Pedro Hispano, a quem disputou pelo menos desde 1263, até possivelmente à morte, o priorado da Igreja de Santa Maria de Guimarães. Sustentou, no tempo, outros conflitos pela posse de benefícios de várias igrejas e veio a fazer o seu testamento fora do Reino, em Burgos, no ano de 1272 .

O seu nome completo é precisamente Fernão Joanes de Portocarreiro, filho de João Henriques de Portocarreiro e de D. Moor Veegas Coronel, como nos elucida o Livro de Linhagens do Conde D. Pedro, que logo acrescenta, quase a oferecer-nos o melhor argumento ou a indicação do caminho mais seguro para esta identificação: Foi daiam de Bragaa, e foi mui boo creligo e foi mui privado d'el rei dom Afonso de Castela, filho d'el rei dom Fernando, o que conquistou a fronteira e nom houve semel (13).

Estes dados harmonizam-se perfeitamente com as referências de Frei Francisco Brandão ao relatar, na Monarquia Lusitana, que muitos portugueses passaram a Castela no tempo de Afonso X, o Sábio.

(13) Portugaliae Monumenta Historica, nova série, vol. II/2, Livro de Linhagens do Conde D. Pedro, ed. crítica por José Mattoso, Lisboa, 1980, 43T4-5, p. 14. Como é óbvio, não é nosso objectivo apresentar, de momento e de uma maneira exaustiva, todos os elementos sobre Fernão Joanes, mas tão só focar alguns dos principais documentos que ajudem a compreender, neste contexto, as suas relações com Castela, a partir de Fernando III. 


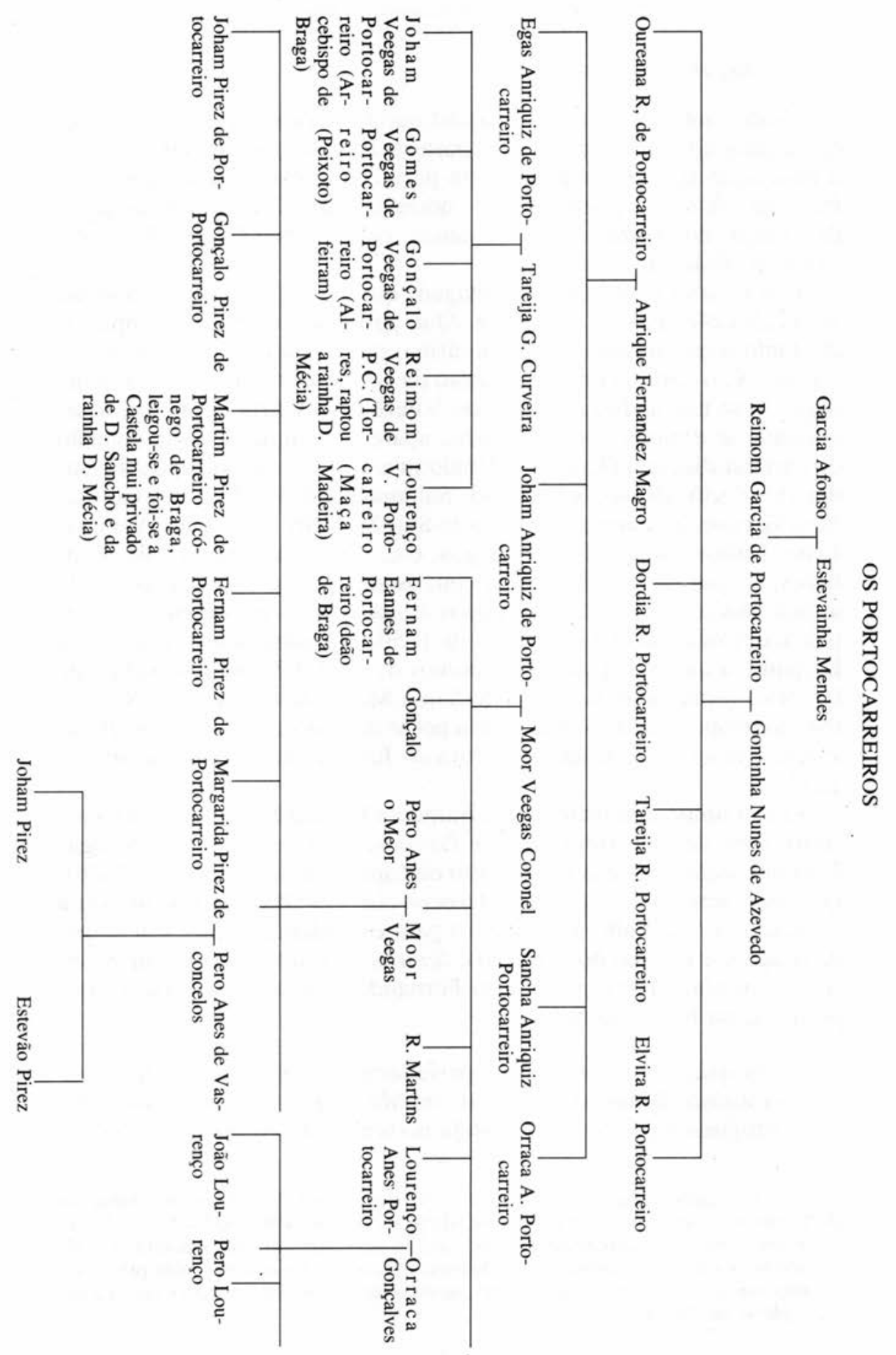


Até porque cita, como principal fonte, precisamente o Conde D. Pedro. Só que Brandão, como não conhecia toda a motivação da saída de muitos portugueses para a corte castelhana, aponta, como únicas causas, aquelas que lhe pareciam mais conformes com a conjuntura do momento. Daí argumentar que uns se ausentaram porque acompanharam D. Sancho II na sua expulsão, outros porque se alistaram no cerco de Sevilha, guerras de Andaluzia ou noutras ocasiões, até serem depois admitidos por D. Afonso III, sobretudo a partir do casamento da rainha D. Beatriz. Que de todos esses portugueses tiveram particular privança com o monarca castelhano, Dom Godinho, natural de Coimbra, dos Godinhos moedeiros, Fernando Annes de Portocarreiro, Deão de Braga e Frei Lope Rodrigues Fafes e Alcoforado religioso da Sagrada Ordem dos Pregadores. E conclui que a capacidade de todos devia ser grande porque num meio tão estranho mereceram a graça de um Rei Sábio, como o Portocarreiro que foi notário daquele monarca castelhano como consta da procuração que fez para a contenda do Reino do Algarve, de que foi um dos juízes ( $\left.{ }^{14}\right)$.

Também Frei António Brandão ao transcrever uma carta de D. Afonso X, datada de Abril de 1253, só vem reforçar a importância da presença do Portocarreiro na corrente castelhana, sinal mais que evidente, pelas circunstâncias que relata, que a confiança nele depositada não deveria remontar apenas ao tempo do seu governo. Nela é mencionado Fernão Joanes, deão de Braga, como notário do referido rei castelhano e um dos procuradores com plenos poderes para tratar e resolver com D. Afonso III de Portugal as contendas sobre os castelos e a terra do Algarve o que, como se sabe, só veio a acontecer, depois do casamento do monarca português com D. Beatriz, filha ilegítima de Afonso X, o Sábio, precisamente no ano de 1253, embora tenha sido posteriormente revalidado, em $1262\left({ }^{15}\right)$.

(14) Monarquia Lusitana, parte V, 1.XVI, c.XXXIX, p. 95v-a. Sobre esta questão parecem-nos ainda pertinentes as observações de José Mattoso, "A crise de 1245", in Revista de História das Ideias, $\mathrm{n} .{ }^{\circ} 6$, Coimbra, 1984, pp. 16-17 ou do mesmo autor Portugal Medieval, Imprensa Nacional-Casa da Moeda, 1985, p. 67. Sobre a família dos Portocarreiros dividida em dois partidos cf. Alexandre Herculano, História de Portugal, t. II, Liv. Bertrand, 1980, pp. 492-497 e nota crítica 92 de José Mattoso no mesmo t. II, pp. 555-556. Como mais abaixo se indica, julgamos que ou relacionado com a situação do Reino no tempo de D. Sancho II ou por motivos de outra ordem, como, por exemplo culturais, já em 1243, estava em Castela, no tempo de Fernando III, tanto mais que posteriormente veio a ser notário do próprio filho Afonso X, o Sábio. A propósito de portugueses nos reinos vizinhos veja-se também Henrique David e J. A. Sottomayor Pizarro, "Nobres portugueses em Leão e Castela», Revista de História, da Faculdade de Letras do Porto, 7, 1987, pp. 135-150.

(15) Cf. Monarquia Lusitana, Parte IV, 1.XV, c.XIII, pp. 194-b e 195-a e b que transcreve a carta do Rei de Castela onde é mencionado Fernando Joanes como notário e procurador do rei castelhano. Ver Antonio Ballesteros Beretta, Afonso X el Sabio, Barcelona, 1984, p. 76 que igualmente chama a atenção para o documento onde 


\section{Na disputa do sagrado e do profano}

D. Afonso III, patrono da Igreja de Santa Maria de Guimarães, dirige-se, por carta de 12 de Dezembro de 1257 ao arcebispo de Braga, D. Martinho Geraldes e apresenta Mestre Pedro Julião (que já era Deão da Sé Lisbonense e Arcediago de Vermoim), para a referida Igreja de Santa Maria de Guimarães (16).

Porém, como a sua confirmação demorasse, Pedro Julião deslocou-se à Cúria Romana, onde foi recebido pelo Papa Urbano IV, e obteve em 28 de Outubro de 1263 o deferimento da sua apresentação.

Feitas as Letras Apostólicas, o pontífice soube que o seu antecessor Alexandre IV tinha permitido ao Arcebispo D. Martinho reter, durante dez anos, desde a sua sagração, a referida Igreja, pelo que mandou suspender as mencionadas Letras e encarregou os cardeais Diogo e Jordão, respectivamente de Santa Maria de Cósmede e de S. Cosme e Damião, de inquirirem se o Arcebispo de Braga consentia na instituição, a favor de Pedro Hispano $\left({ }^{17}\right)$. Os cardeais, tendo examinado as cartas, tanto de D. Afonso III, como do arcebispo, e ouvido outras testemunhas, concluíram que o arcebispo dava o seu assentimento, pelo que investiram pessoalmente Pedro Julião com os seus anéis, entregando-lhe a Igreja, sem ter que renunciar a outros benefícios que já possuía. Então Urbano IV confirmou esta decisão dos cardeais e confiou ao Arcebispo de Braga que investisse e protegesse Mestre Pedro Julião. A verdade, porém, é que nenhum processo se efectuou ( $\left.{ }^{18}\right)$ e o que se sabe é que, entretanto, D. Afonso III, patrono da mesma Igreja, apresentou, sem questão, Fernão Joanes, deão de Braga, para

sobre esta contenda se faz clara referência a Fernando Yánez, deán de Braga y notario entre outros confirmantes também com plenos poderes. Veja-se ainda sobre a questão do Algarve, José Mattoso, Fragmentos de uma composição medieval, Lisboa, 1987, pp. $84-88$.

(16) A carta de D. Afonso III sobre a apresentação de Pedro Hispano à Igreja de Santa Maria de Guimarães, enviada ao Arcebispo, encontra-se inserida e transcrita na bula de Urbano IV, Ex paterna quam, de 23 de Outubro de 1263, dirigida a mestre Pedro Julião. Cf. Artur Moreira de Sá, Pedro Hispano Prior da Igreja de Santa Maria de Guimarães e Arcebispo da Sé de Braga, Coimbra, 1955, cujo texto latino e tradução transcreve, assim como outros documentos, pp. 10-24 e ainda do mesmo autor Primórdios da cultura portuguesa, Lisboa, 1966, pp. 71-73. Toda esta questão foi também por nós já abordada noutro trabalho pelo que apresentamos apenas um resumo (Cf. José Antunes, «O percurso e o pensamento político de Pedro Hispano, Arcebispo-eleito de Braga e Papa João XXI» in IX Centenário da Dedicação da Sé de Braga. Congresso internacional-Actas, Braga, 1990, pp. 125-184.

(17) Idem, bula Ex paterna quam, onde se relatam estes factos. Cf. nota anterior e Artur Moreira de Sá, Pedro Hispano Prior da Igreja de Santa Maria de Guimarães, ob. cit., pp. 3-4; 10-15. Cf. José Antunes, ob. cit., pp. 141-142.

(18) Idem, bula Ex paterna quam, onde igualmente se transcreve o doc. dos dois cardeais, com data de 19 de Outubro de 1263, endereçado a Pedro Julião, mas em termos altamente elogiosos para o Mestre e até fora do vulgar em documentos desta natureza. Cf. José Antunes, ob. cit., p. 142. 
a mesma Igreja, o que levou o Arcebispo a dilatar a investidura por entender, em consciência, que o deão não podia receber os rendimentos da Igreja, se fosse investido ${ }^{(19)}$.

Esta situação é igualmente referida pela bula de Clemente IV de 29 de Julho de 1268, onde se afirma, claramente, que o deão de Braga se fez apresentar pelo rei, na ausência do arcebispo e que sob o pretexto de tal apresentação, comendação e instituição detinha e ocupava, contra a justiça, o priorado da Igreja em prejuízo e afronta do Mestre (20).

Depois de várias e complexas vicissitudes, a Cúria papal decidiu a favor de Pedro Hispano, apesar de todos os embargos levantados pelo deão e de nova aposentação pelo rei, tendo Clemente IV ordenado ao bispo da Ciudad Rodrigo para investir e proteger Pedro Julião ou o seu procurador e afastar definitivamente o deão Fernão Joanes da posse da mencionada Igreja. De facto, em 2 de Janeiro de 1273 (isto é, depois de 16 anos de conflito), Mestre Estevão, arcediago de Braga, acabou por investir, em representação do arcebispo da Ciudad Rodrigo, Mateus Nunes, cónego de Guimarães, procurador do Mestre Pedro Julião, na referida Igreja de Santa Maria de Guimarães e suas pertenças. E a 6 de Fevereiro, também de 1273, escreve a D. Afonso III, a comunicar-lhe a solução ${ }^{(21)}$.

Estes são os factos mais importantes que rodearam a longa disputa dos dois deãos Fernando Joanes e Pedro Julião, respectivamente das Sés de Braga e de Lisboa pela posse da Igreja de Santa Maria de Gui-

(19) O documento aparece sob o título Memorandum de 1264 (?) cf. Artur Moreira de Sá, ob. cit., pp. 5-7; 15-16. Martinho foi Arcebispo de Braga de 1256 a 1271. Se podia reter os rendimentos da Igreja durante dez anos esse período terminaria possivelmente em 1266. Mas como ainda faltavam dois anos, como o próprio documento esclarece, para que terminasse o prazo, levanta-se a hipótese do documento ser do ano de 1264. Sobre a elevação de D. Martinho ao Arcebispado de Braga, cf. José Augusto Ferreira, Fastos Episcopaes da Igreja Primacial de Braga. T. II, Ed. da Mitra Bracarense 1930, pp. 49-50. Cf. José Antunes, ob. cit., p. 143. Depois de termos concluído, no fundamental, o presente trabalho, defendeu e publicou a estimada colega Doutora Maria Alegria F. Marques a sua tese de doutoramento intitulada $O$ papado e Portugal no tempo de D. Afonso III (1245-1279), Coimbra, 1990, que teve a gentileza de nos oferecer e que muito penhoradamente agradecemos. Apraz-nos, no entanto, registar, que muitos dos elementos informativos que nos oferece e a que gratamente faremos referência, longe de nos contradizerem, só vieram, ao que julgamos, reforçar as hipóteses e conclusões a que chegámos. Veja-se, da autora, ob. cit, p. 199 , n. 159.

(20) Cf. docs. em Artur Moreira de Sá, ob. cit., pp. 5-6, 18 e 21 e José Antunes, ob. cit., p. 143 .

(21) Trata-se de uma carta enviada a D. Afonso III sob o título: A El-Rei. Sentença pela qual lhe foi julgado o padroado Igreja de Santa Maria de Guimarães, no Arcebispado de Braga. Nela se transcreve a carta do bispo da Ciudad Rodrigo e a bula de Clemente IV Constitutus in praesentia, de 29 de Julho de 1268. Cf. Artur Moreira de Sá, ob. cit., pp. 5-7 e 16-22 e José Antunes, ob. cit., p. 144. 


\section{Universidade}

marães que, comparada com os milhares de Igrejas do Reino, era a mais rica de todas, suplantando, inclusivamente, como já escrevemos, muitos dos maiores mosteiros (22).

Esta situação de padroado que os reis de Portugal exerciam relativamente a certas Igrejas foi, como se sabe, e frequentemente, objecto de largas e fortes contestações. A cada passo os monarcas possivel-

(22) Como já tivemos ocasião de demonstrar noutro lugar (ver José Antunes, $o b$. cit., pp. 145-146), uma das causas desta tão prolongada e persistente demanda, era, certamente, o grande valor dos rendimentos do Priorado da Igreja de Santa Maria de Guimarães, que julgamos importante frisar, para melhor compreendermos a questão.

Os dados que possuímos são tardios, mas podem por analogia, servir de um bom sinal indicativo e permitem uma comparação com Pedro Hispano (Cf. José Antunes, ob. cit., p. 146). Referimo-nos à avaliação dos rendimentos em libras, das Igrejas, mosteiros e benefícios eclesiásticos dos arcebispados e bispados do Reino que constam do manuscrito $n .^{\circ} 179$ da Biblioteca Nacional de Lisboa, de grafia do século XVIII, e que Fortunato de Almeida reproduziu na sua obra História da Igreja em Portugal, vol. IV, Porto-Lisboa, 1971, pp. 90-144, intitulado: Catálogo de todas as Igrejas, comendas e mosteiros que havia nos reinos de Portugal e Algarves pelos anos 1320 e 1321, com a lotação de cada uma delas. Ano de 1746. Por este documento se conclui que a Igreja de Santa Maria de Guimarães, pela parte que toca à mesa prioral, foi taxada em 1600 libras e o cabido da mesma em 2000. Comparámos estes valores com os rendimentos dos milhares de Igrejas no Reino e verificámos que era a mais rica de todas suplantando inclusivamente os da maioria dos mosteiros.

Para dar uma ideia aproximada da importância de alguns rendimentos de Fernão Joanes, no que respeita às Igrejas, cujos benefícios temporária ou permanentemente usufruiu, veja-se o seguinte quadro:

\begin{tabular}{|c|c|c|}
\hline CARGOS & LIBRAS & $\begin{array}{l}\text { FONTE: Fortunato de Almeida, História } \\
\text { da Igreja em Portugal. Nova ed. prepara- } \\
\text { da por Damiâo Peres, IV vol., Porto Edi- } \\
\text { tora, 1971, p. 99-144. }\end{array}$ \\
\hline Deado da Sé de Braga & 450 & p. 97 \\
\hline Igreja de Santa Maria de Torres Vedras & 700 & p. 130 \\
\hline $\begin{array}{l}\text { Igreja de Santa Maria de Guimarães pela } \\
\text { parte que toca à mesa prioral }\end{array}$ & 1600 & p. 108 \\
\hline Igreja de S. Pedro do Sul & 300 & p. 119 \\
\hline Igreja do Monte Córdova & 150 & p. 95 \\
\hline Igreja de S. Estêvão de Alenquer & 200 & p. 129 \\
\hline Igreja de Santa Maria do Vimieiro & 100 & p. 97 \\
\hline Igreja de Santa Maria de Tavira & 380 & p. 133 \\
\hline Igreja de Santa Maria Castrelo de Orense & $?$ & \\
\hline Mosteiro de Celanova & ? & \\
\hline Total em libras .... & 3880 & \\
\hline
\end{tabular}


mente como recompensa de serviços prestados pelos súbditos conferiam Igrejas e benefícios eclesiásticos a quem lhes aprazia ou, noutros casos, destituíam e expulsavam pessoas que tinham sido até, canonicamente providas, pelos respectivos prelados. De facto, um dos artigos das queixas apresentadas em 1267 ao Papa contra D. Afonso III era exactamente que o monarca impunha «a seu bel-prazer priores, abadessas de mosteiros e reitores de paróquias a renunciarem esses cargos e benefícios, sobretudo sendo em Igrejas ou mosteiros em que pretendia ter direito de padroado" $\left({ }^{23}\right)$.

Aliás, esta possível e costumada exorbitância foi-lhe igualmente apontada, embora mais tarde, precisamente pelo próprio papa João XXI (outrora também vítima, como vimos, dum provável e semelhante abuso), quando, na Bula Jucunditatis et exultationis, lhe recorda: «não julgues que queremos lesar em alguma coisa os teus direitos pelo facto de, por imperativo de consciência, mandarmos destituir canonicamente, por Letras Apostólicas, algumas pessoas que tinham sido instituídas menos canonicamente nas Igrejas do teu Reino» (24).

Deste modo, os factos que referimos sobre a concessão de vários benefícios a Fernão Joanes e até os conflitos que a posse de alguns desses bens desencadearam enquadram-se perfeitamente neste contexto. $\mathrm{E}$, além do mais, ajudam a compreender melhor o clérigo medievo, sobretudo das catedrais que com os das colegiadas, constituíam, no dizer de Gama Barros, «uma espécie de aristocracia entre o clero secular" (25). E também o tipo de pessoas ou de conselheiros que se movimentavam tanto junto dos monarcas, como na Cúria Pontifícia, e ainda o porquê de certas intervenções régias, a natureza das súplicas que subiam até ao Papa, oferecendo, assim, elementos válidos que, certamente, não deixam de contribuir para uma melhor informação e conhecimentos do período a que nos reportamos.

Nesta ordem de ideias convém registar que já em 22 de Fevereiro de 1245, Inocêncio IV, pela bula Apostolica Sedis benignitatis, concede a Fernão Joanes, cónego de Braga e reitor da Igreja de Santa Maria de Torres Vedras, da diocese de Lisboa e capelão do cardeal-diácono de Santa Maria in Via Lata, Octaviano Ubaldini, a faculdade de usufruir outros benefícios até duzentos marcos de prata por ano (26).

(23) Cf. Fortunato de Almeida, História da Igreja em Portugal, I, Porto, 1967, p. 190; Alexandre Herculano, História de Portugal, Tomo III, Livraria Bertrand, pp. 131-132, nota crítica 84 de José Mattoso, p. 210. Sobre padroeiros veja-se ainda Fortunato de Almeida, ob. cit., pp. 106-108.

(24) Para o texto latino da Bula e respectiva tradução ver José Antunes, ob. cit., pp. 159-163.

(25) Gama Barros, História da Administração Pública em Portugal nos séculos XII a $X V, 2$ a $^{\text {a }}$ ed. dir. por Torquato de Sousa Soares, Tomo II, Lisboa, 1945, p. 76. Cf. Fortunato de Almeida, ob. cit., I, p. 102.

(26) Doc. em Augusto Quintana Prieto, La documentación Pontifícia de Inocên- 
Em 1257 é Afonso X de Castela que, por sua vez, apresenta o deão de Braga para reitor da Igreja de Santa Maria de Castrello, apesar da forte oposição do referido bispo de Orense, D. Juan Diaz, que chegou a ser esbofeteado, quando procurou excluir da referida Igreja Fernão Joanes Portocarreiro, candidato do rei e que acabou por ser confirmado na mesma pelo próprio papa, então Alexandre IV (27). Porém, já antes, ou mais concretamente em 1255, o mesmo monarca castelhano, precisamente em atenção ao referido arcebispo bracarense D. João Viegas Portocarreiro e a Fernão Joanes (referência, aliás, bastante significativa) tinha confirmado a doação à Sé de Braga de Erveredo, Bustelo, e Agela com metade da respectiva moeda e franquias que os bispos de Leão possuíam nos mencionados coutos ${ }^{(28)}$.

Mas ainda em 1257, no dia 1 de Setembro, o mesmo papa Alexandre IV, concede a Fernão Joanes, então já seu capelão, o poder de possuir vários benefícios eclesiásticos até 40 marcos de prata (29).

Em 1261 o deão de Braga tem uma questão com a Ordem do Templo, acerca da Igreja de Santiago de Santarém, conforme se infere, da sentença do monarca português a favor do mestre e dos próprios freires ( ${ }^{30}$ ). Não obstante, já nos anos seguintes é apresentado pelo mesmo monarca D. Afonso III, isto é, em 1262, para a Igreja de S. Pedro do Sul e em 1263 para a Igreja de Santo Estevão de Alenquer ( ${ }^{31}$ ).

No dia 26 de Julho, também de 1263, estabelece uma composição com D. João Martins, abade do mosteiro de Celanova, em Leão, com a intervenção de D. Juan Díaz, bispo de Orense e delegado do papa, pelo qual o deão de Braga poderia reter, como benefício, todos os fru-

cio IV (1243-1254), I, Roma, 1987, pp. 122-123, n. ${ }^{\circ}$ 108. Peter Linehan, na sua obra La iglesia española y el papado en el siglo XIII, Salamanca, Universidad Pontificia, 1975 , p. 263 , n. ${ }^{\circ} 138$, afirma que o deão foi capelão do cardeal durante 12 anos, pelo menos (cf. ainda p. 117, n. ${ }^{\circ} 97$ e 179, n. 109-110). Veja-se ainda Maria Alegria F. Marques, ob. cit., pp. 157 e 197, n. ${ }^{\circ} 144$ e 152, 191 sobre a Igreja de Sta. Maria do Vimieiro.

(27) Ver os docs. de 1 de Março e 12 de Janeiro de 1257 referentes à confirmação de Fernão Joanes em Ildefonso Rodrigues Lama, La documentación pontificia de Alejandro IV (1255-1261), I, Roma, Instituto Español de Historia Eclesiástica, 1976, pp. 229-230, n. ${ }^{\circ} 240$; p. 209 , n. ${ }^{\circ} 212$ e ainda as importantes informações e referência às fontes em Peter Linehan, ob. cit., p. 179, n. 109-110. Cf. Maria Alegria F. Marques, ob. cit., pp. 157 e 197, n. 148.

(28) T.T. - C. R. Mitra de Braga, m. 3, n. 97. Cf. José Augusto Ferreira, Fastos Episcopaes da Igreja Primacial de Braga, T. I, ed. da Mitra Bracarense, 1930, pp. 390-391 e Maria Alegria Fernandes Marques, ob. cit., pp. 157 e 197, n. 147.

(29) Ver doc. em Ildefonso Rodriguez Lama, I, ob. cit., p. 269, n. 284, Cf. Maria Alegria F. Marques, ob. cit., pp. 157 e 198, n. 149.

(30) T.T. Chancelaria de D. Afonso III, fol. 55v; Cf. Artur Moreira de Sá, Pedro Hispano prior da Igreja de Santa Maria de Guimarães, cit., pp. 23-24; José Antunes, ob. cit., p. 150 e Maria Alegria F. Marques, ob. cit., pp. 157 e 198, n. 151. (31) T.T. - Gav. 10, m. 3, n. ${ }^{\circ} 15$. Cf. Maria Alegria F. Marques, ob. cit., pp. 157 e 198, n. 152. 
tos, proventos e prestimónios do mosteiro, com algumas excepções. Registe-se, no entanto, que este acordo foi confirmado, a pedido do próprio Fernão Joanes, pelo monarca castelhano Afonso X, tal a importância e o valor que a celebração do acto tinha para o deão interessado $\left.{ }^{32}\right)$.

Por todo o curso do ano de 1264 , encontra-se na corte de D. Afonso III, conforme testemunham vários diplomas datados desse mesmo ano e emanados de Lisboa, Beja e Santarém ( ${ }^{33}$ ). Porém, relacionado ou não com este acompanhamento do rei, sabemos, como igualmente atestam os documentos, que em 1265 ainda foi apresentado pelo mesmo monarca para a Igreja de Santa Maria de Tavira ( ${ }^{34}$ ).

Em 12 de Março de 1269 estabelece um acordo sobre prebendas com o cabido da Igreja de Santa Maria de Guimarães (35). E finalmente, em 10 de Dezembro de 1272, no reino de Castela, ou mais concretamente, na cidade de Burgos, faz o seu testamento de todos os bens, onde ainda se intitula deão de Braga e Prior de Guimarães - Ego fernandus iohannis decanus Bracarensis et prior Vimaranis (36).

Ao lado de que poder?

Digna de nota é também a oposição que Fernando Joanes de Portocarreiro muito antes da questão com Pedro Hispano moveu a D. Pedro Salvadores, bispo do Porto.

(32) A.D.B. - Gav. dos Arcebispos, 33. Gav. das Religiões e Mosteiros, n. 10. Cf. Peter Linehan, ob. cit., p. 228, n. 39 e Maria Alegria F. Marques, ob. cit., p. 157 e 198, n. 153.

(33) T.T. - C.R., Santa Cruz, DR; m. 3, n. ${ }^{\circ} 14$ e m. 3, n. ${ }^{\circ} 16 ;$ T.T. - Chanc. de Afonso III, Liv I, fls. $72-72$ e 108; T.T. - Santa Maria de Aguiar, m. 5, n. ${ }^{\circ}$ 14; T.T. - Chanc. de Afonso III, Liv. I, fl 72, cf. J. J. Alves Dias, «Itinerário de D. Afonso III (1245-1279)», Arquivos do Centro Cultural Português, 15, pp. 453-519 e Maria Alegria F. marques, ob. cit., p. 157 e 199, n. 155.

(34) T.T. - Gav. $10, \mathrm{~m} .3$, n. ${ }^{\circ} 15$. É possível que possuísse outros bens no Algarve. Veja-se uma leve referência no foral de Loulé de 1266 (Portugaliae Monumenta Historica, Leges et Consuetudines, Lisboa, 1856, vol. I, p. 736) sobre uma adega, que passou para o rei. Cf. Maria Alegria F. Marques, ob. cit., pp. 157 e 199, n. 156 .

(35) Trata-se da renovação de uma carta do prior e cabido de Guimarães, prometendo não dar cartas a ninguém sobre prebendas canónicas não vagas. Veja-se o doc. em Maria Ângela Beirante, Estudo de alguns documentos da Chancelaria de D. Dinis. Livro II, fólios 7-57v (1291-1293). Dissertação de licenciatura, mimeografada. Coimbra, Faculdade de Letras, 1969, pp. 129-131, n. ${ }^{\circ} 60$ e Maria Alegria F. Marques, ob. cit., pp. 157 e 199, n. 157.

(36) O testamento encontra-se no Arquivo Distrital de Braga, Gaveta dos Testamentos, $\mathrm{n} .{ }^{\circ} 31$. Transcrito no Livro $1 .^{\circ}$ dos Testamentos, $\mathrm{n} .{ }^{\circ} 24$. Publicado parcialmente por Isaías da Rosa Pereira, Livros de Direito na Idade Média, Lisboa, 1966, pp. 17-18; por Artur Moreira de Sá, Primórdios da Cultura Portuguesa, Lisboa, 1966, pp. 104-105 e José Antunes, ob. cit., p. 147. Rel. em Peter Linehan, ob. cit., p. 228 e Maria Alegria F. Marques, ob. cit., p. 157 e 199, n. 158. 


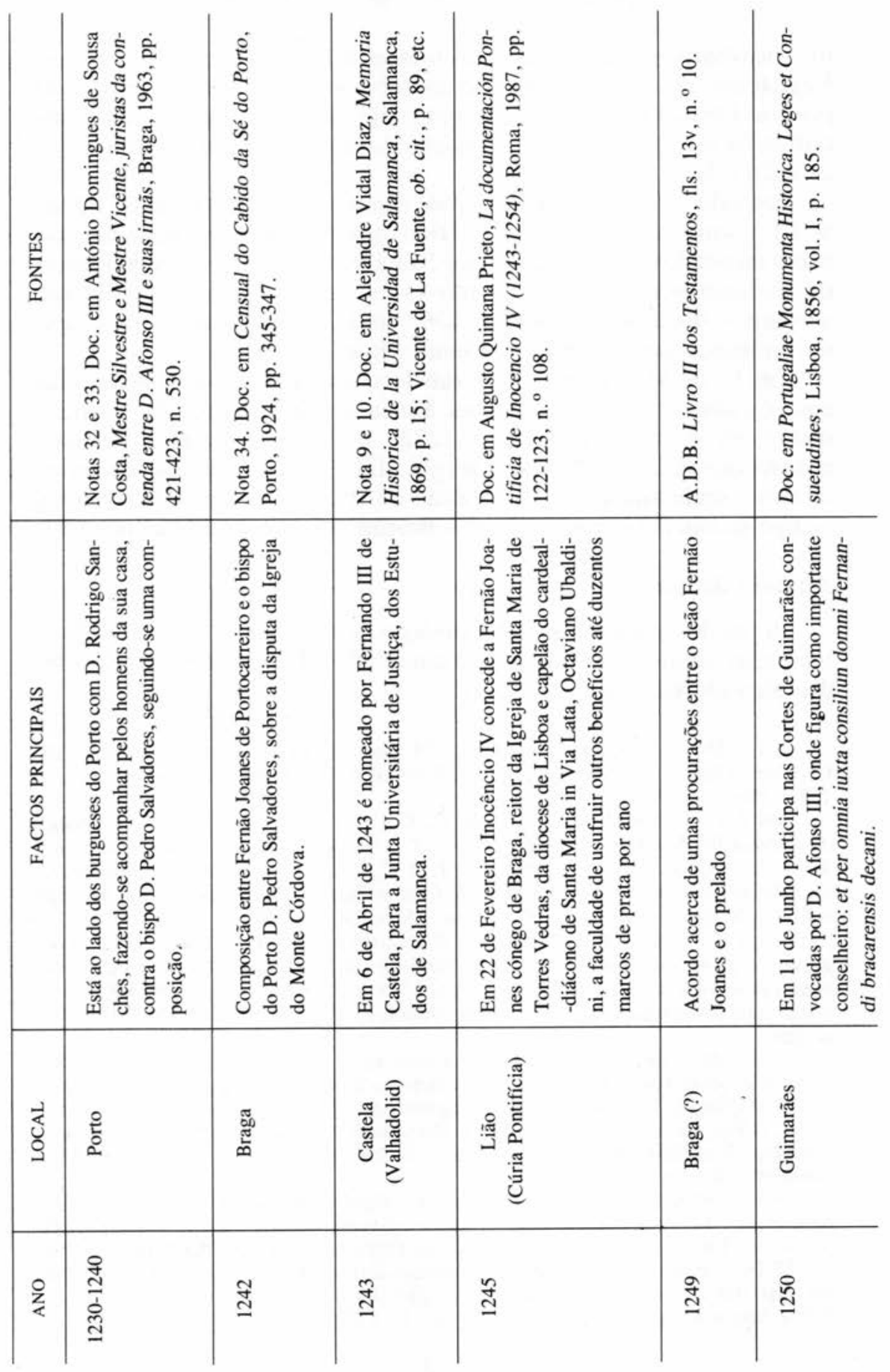




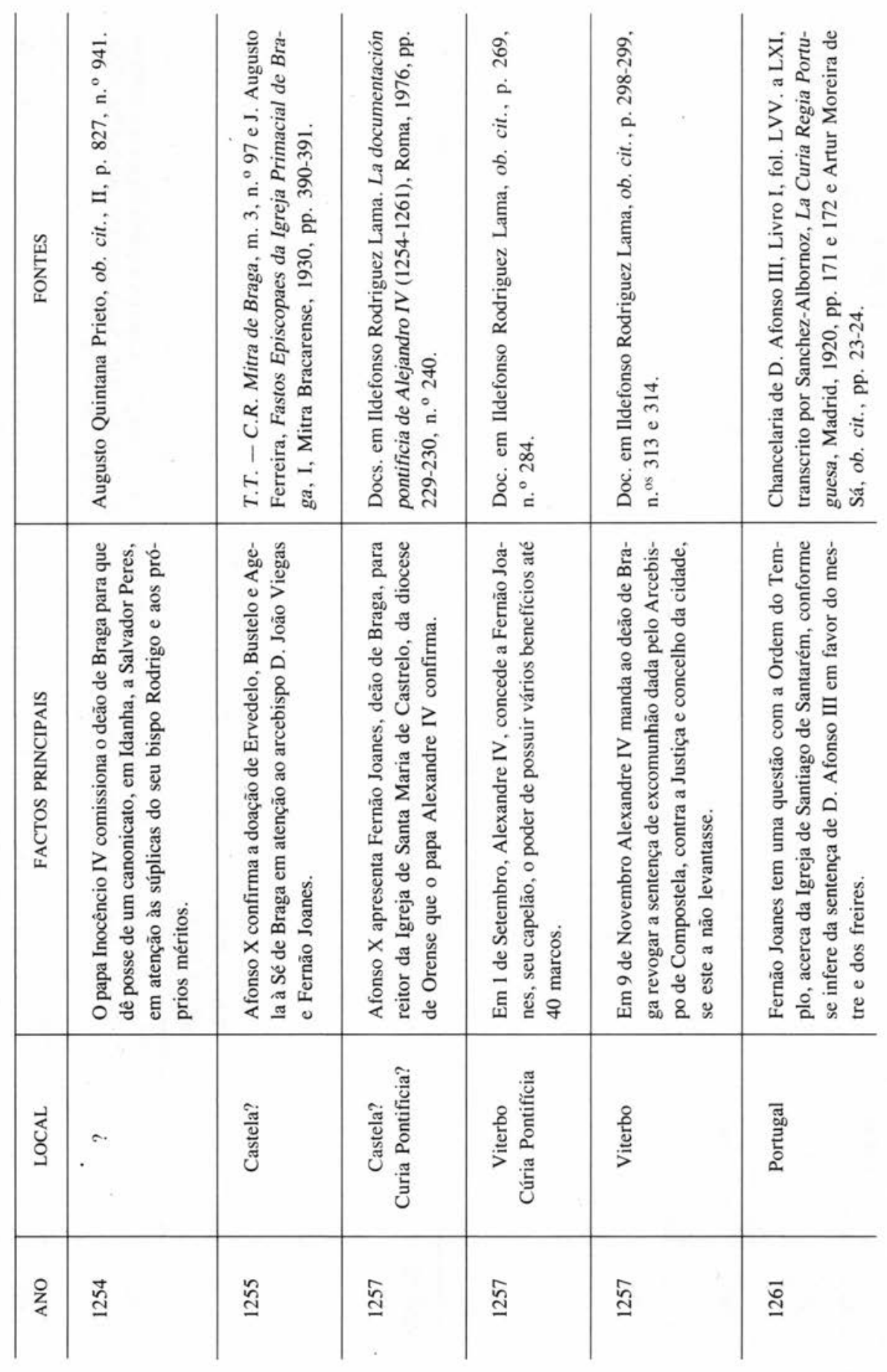




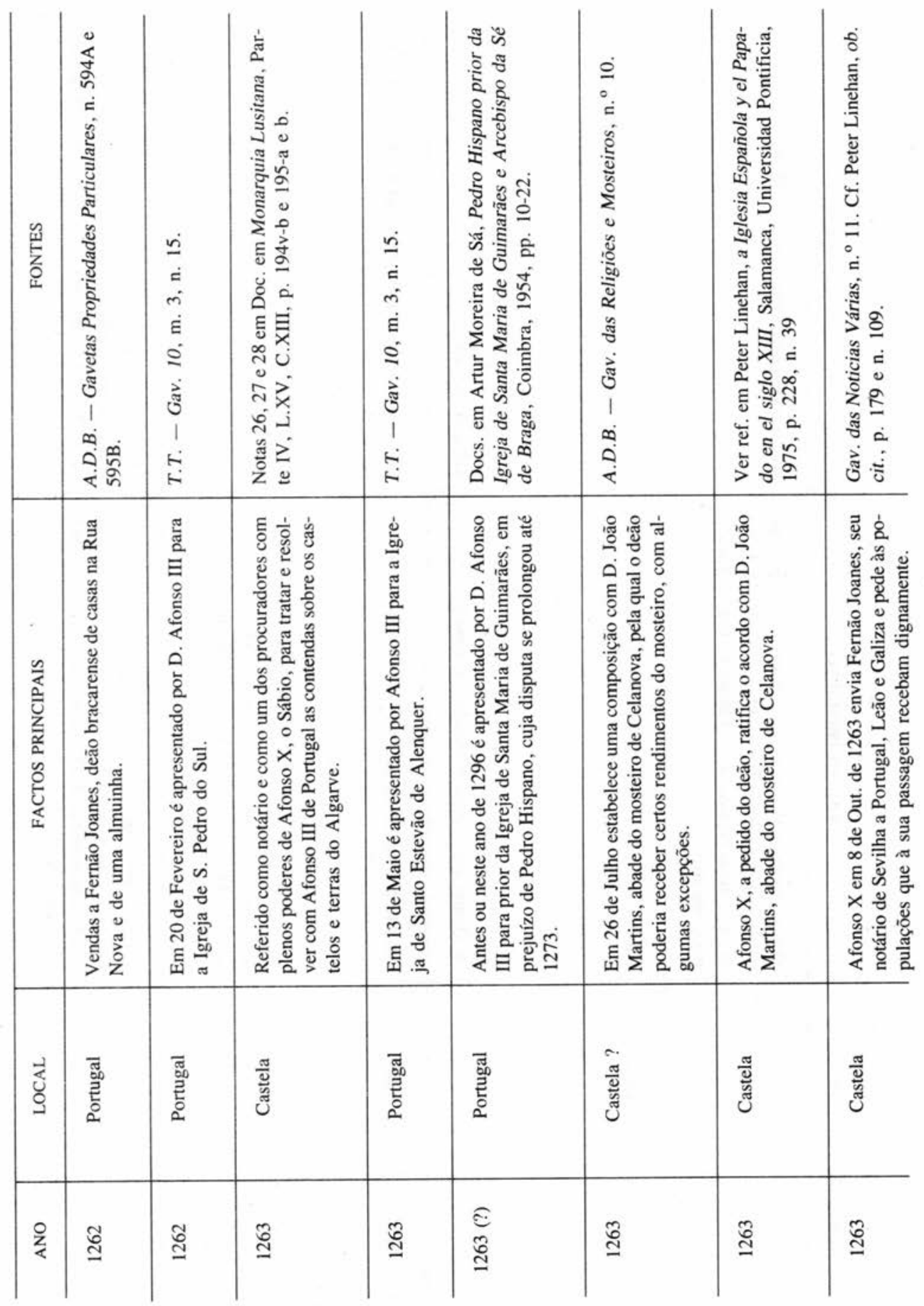




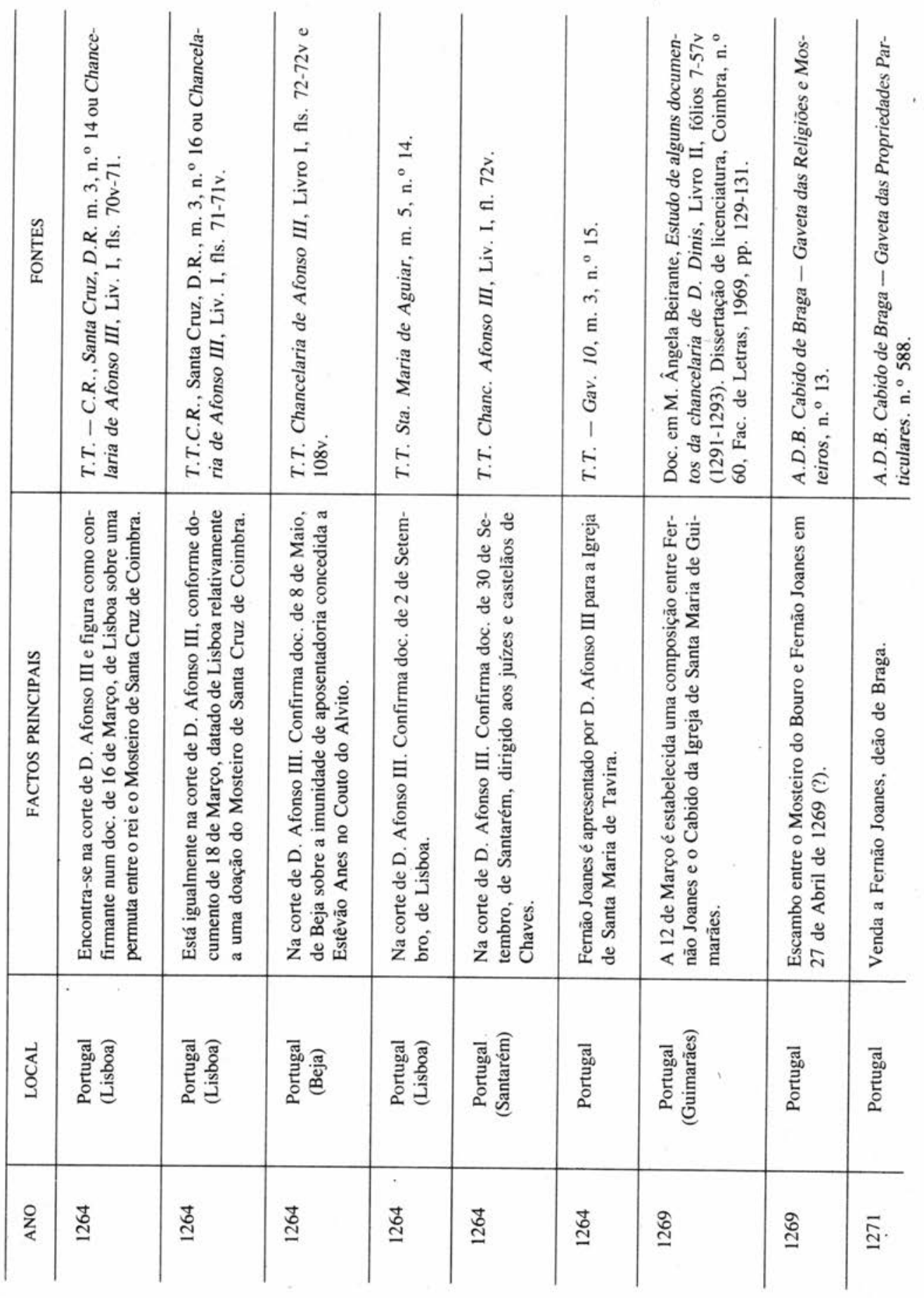




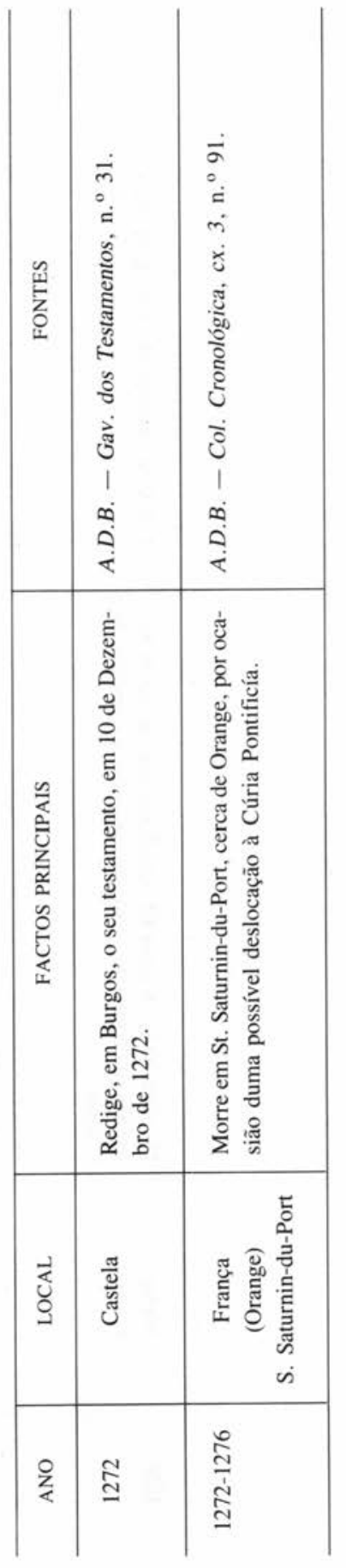


Normalizadas as relações entre este prelado e D. Sancho II, pela concórdia que teve o seu início em Maio e terminou em Agosto de $\left.1238{ }^{(37}\right)$, os burgueses portuenses como no tempo do conflito entre o bispo D. Martinho Rodrigues e D. Sancho I, persistiram na sua luta contra o bispo durante mais de dois anos (1238-1240).

D. Pedro Salvadores, talvez para quebrar a resistência dos seus vassalos, em certa rebelião contra a sua actuação, confiou o governo da cidade a alguns fidalgos que foram bastante severos para com os burgueses. Estes redigiram então uma espécie de carta-manifesto que enviaram aos bispos, prelados das Igrejas e mais fiéis, queixando-se amargamente do seu bispo, cujos direitos estavam prontos a reconhecer conforme o que resolvesse o Arcebispo de Braga D. Silvestre Godinho, ou D. Sancho II, mas que o seu prelado rejeitava a apelação e os fidalgos se comportaram com tal dureza que chegaram a enforcar alguns e a vender por dinheiro os seus filhos e mulheres como se fossem mouros $\left({ }^{38}\right)$.

Ora sabe-se que nesta rebelião o concelho do Porto era apoiado pelas armas de D. Rodrigo Sanches, filho bastardo de D. Sancho I, tio de D. Sancho II (e seu lugar tenente em grande parte do território de entre Lima e Douro) que, como qualquer cónego, possuía também prebendas e ração de comestíveis na Sé Catedral. E ainda pelo chantre e mais tarde deão da Sé de Braga, Fernando Joanes de Portocarreiro, que deveria ser homem bastante poderoso (porquanto se fazia acompanhar dos homens da sua casa) ( ${ }^{39}$ ) e que, por sua vez, disputava ao bispo portuense o padroado da Igreja do Monte Córdova.

Influenciados ou não por D. Sancho II, os cidadãos do Porto acabaram por chegar também a um acordo com D. Pedro Salvadores, em Setembro de 1240, por meio de D. Tibúrcio, bispo de Coimbra e de Abril Peres, senhor de Lumiares que, na opinião de Luís Gonzaga de

(37) A composição encontra-se transcrita por António Domingues de Sousa Costa, Mestre Silvestre e Mestre Vicente, juristas da contenda entre D. Afonso III e suas irmãs, Braga, 1963, nota 524, pp. 413-418. Em complemento destes factos ver António Cruz, "Os Bispos Senhores da Cidade. II. De D. Pedro Salvadores a D. Vasco Martins", in Historia da Cidade do Porto, (dir. por A. Cruz e D. Peres) I, Porto, 1962, pp. 190-194; Alexandre Herculano, ob. cit., t. II, pp. 454-459 e notas críticas 73 a 75 de José Mattoso, no mesmo t. II, pp. 552-553; José Augusto Ferreira, Memórias Arqueológico-Históricas da Cidade do Porto, I, Braga, 1923, pp. 225-230. Luiz Gonzaga de Azevedo, História de Portugal, t. VI, Lisboa, 1944, pp. 64-80. José Antunes, António Resende de Oliveira e João Gouveia Monteiro, «Conflitos políticos no Reino de Portugal entre a Reconquista e a Expansão", Revista de História das Ideias, n. ${ }^{\circ}$ 6, Coimbra, 1984, pp. 92-95.

(38) Cf. a Carta-Manifesto do concelho do Porto contra D. Pedro Salvadores (1238-1240) in Luiz Gonzaga de Azevedo, ob. cit., vol. VI, pp. 188-191.

(39) «... et per Fernandum Iohannis canonicum Bracharensem et homines de domo sua et per omnes alios de parte eorundem Civium...». Cf. o texto em António Domingues de Sousa Costa, ob. cit., nota 530, p. 422. 
Azevedo, foram impostos como árbitros a ambas as partes, por D. Rodrigo Sanches. Então, os burgueses foram condenados a pagar dois mil aureos de indemnização ao bispo, por perdas e danos, comprometendo-se D. Pedro Salvadores a não entregar o governo da cidade aos fidalgos e a levantar todas as excomunhões. Além disso, tanto D. Rodrigo Sanches, como Fernando Joanes e o bispo portuense deviam perdoar-se mutuamente de todo o rancor e sofrimento causados $\left({ }^{40}\right)$.

De facto, a composição entre D. Pedro Salvadores e Fernando Joanes de Portocarreiro, sobre a Igreja do Monte Córdova, teve lugar no próprio Cabido de Braga, a 5 de Julho de 1242, por influência de amigos comuns que se interpuseram para encontrar uma solução $\left({ }^{41}\right)$.

Alguns autores acentuam, que Fernando Joanes de Portocarreiro, assim como o seu irmão, Gomes Anes pertencia ao partido de D. Sancho II e, obviamente, era opositor ao Conde de Bolonha, ausentando-se por tal motivo, para Castela ( ${ }^{42}$ ). Ora, como o identificamos com Fernando Joanes de Portocarreiro de que fala o documento de Fernando III, já, portanto, em 1243, estava ou passava por Castela. Por isso, nada repugna que a sua presença em terras castelhanas estivesse relacionada com as Escolas de Salamanca (por motivos de estudo ou por outras razões), ou, até mesmo, pela grave situação que já em 1243 se vivia em Portugal, tanto mais que muitas das verdadeiras causas da chamada crise de 1245 vinham de longe $\left({ }^{43}\right)$.

(40) Veja-se o texto da concórdia em António Domingues de Sousa Costa, ob. cit., pp. 421-423, n. ${ }^{\circ} 530$ e Alexandre Herculano, ob. cit., pp. 458-461 e notas críticas de José Mattoso, 74-75 e 92, pp. 552-553 e 555-556. Luiz Gonzaga de Azevedo, ob. cit., pp. 78-79; José Antunes, António Resende de Oliveira e João Gouveia Monteiro, ob. cit., pp. 94-95.

(41) O documento de composição, sob o título Conuenjentia inter petrum episcopum portugalensem et fernandum iohannis super ecclesia Montis Cordube encontra-se na íntegra no Censual do Cabido da Sé do Porto, Porto, 1924, pp. 345-347. O conflito entre ambos deveria ter sido profundo, a avaliar pelas seguintes expressões: «Et fernandum iohannis canonicum Bracharensem super pluribus Articulis orta esset materia quaestions et peccatis exigentibus magna discordia esset orta quae utramquem partem diutius fatigauit. ex qua discordia Episcopus affirmabat se multa dampna et iniurias incurrisse et altera pars similiter. Tandem utraque pars desiderans amicabiliter inter se concordare amicis utriusque partis interponentibus partes suas ita concordaverunt...». Cf. Luiz Gonzaga de Azevedo, ob. cit., p. 91 e ainda 20, 77 e 156 e nota crítica 92 de José Mattoso, in Alexandre Herculano, ob. cit., pp. 555 e 556.

(42) Monarquia Lusitana, Parte V, 1.XVI, c.XXXIX, p. 95v-a. Ao ler-se Luiz Gonzaga de Azevedo, ob. cit., pp. 20, 77, 91 e 156 fica-se na dúvida se este historiador julga Fernando Joanes de Portocarreiro do partido de D. Sancho II. Veja-se ainda nota crítica 92 de José Mattoso, in Alexandre Herculano, ob. cit., pp. 555-556. Quanto a Gomes Anes sabe-se que foi censurado no inquérito de 1252, em Coimbra, pelas violências aí praticadas durante a guerra civil. Cf. a referida nota 92 de José Mattoso.

(43) Fica, assim, provado, por este documento de 1243, que Fernão Joanes se encontrava em Castela dois anos antes de 1245. 
Mas nós temos alguma dificuldade em definir ou partidarizar um eclesiástico desta natureza.

Porque, se em 1242 estava ao lado dos burgueses do Porto, ligando-se a D. Rodrigo Sanches, tio e lugar tenente do rei D. Sancho II, contra D. Pedro Salvadores, tal facto não significa que fosse realmente da facção do rei visto que então disputava, fortemente, ao bispo portuense, a Igreja do Monte Córdova. Além disso, em 1250, já tomava parte nas Cortes de Guimarães, convocadas por D. Afonso III, como referem os documentos: et per omnia juxta consilium domni $F$. bracarensis decani magistri Petri Yspani Ulixbonensis decani... Em 1253 aparece como notário e procurador entre outros, de Afonso X, o Sábio, com todos os poderes para tratar e resolver com D. Afonso III de Portugal as contendas sobre o Algarve para cuja solução não foi alheio o casamento da filha ilegítima do rei castelhano, a rainha D. Beatriz, com o monarca português. E posteriormente a 1257 é apresentado por D. Afonso III para prior da Igreja de Santa Maria de Guimarães, em prejuízo de Pedro Hispano.

É verdade que alguns dos seus primos directos (da parte, portanto, da turbulenta família dos Portocarreiros), pertenciam claramente ao partido do Conde de Bolonha e foram fortes conspiradores contra D. Sancho II. Assim, o arcebispo de Braga, D. João Viegas de Portocarreiro (1245-1255) tomou parte no Concílio Ecuménico de Lião e foi um dos bispos que pediu ao Papa Inocêncio IV a deposição do monarca e posteriormente com outros e com o seu irmão Gomes Viegas de Portocarreiro recebeu em Paris o juramento do Conde de Bolonha. E Reimão Viegas de Portocarreiro, igualmente irmão é vigorosamente censurado no Livro de Linhagens do Conde D. Pedro pelo seu crime de traição porquanto, sendo vassalo d'el rei, não só quebrou o seu compromisso de fidelidade, como lhe raptou em Coimbra a esposa, a rainha D. Mécia, levando-a para Ourém e acabando por voltar as armas contra o próprio rei, seu senhor $\left({ }^{44}\right)$.

Porém, a posição do deão de Braga face a estes dois partidos em presença já não transparece com tanta clareza. Revela-se com um comportamento mais fluido conforme as circunstâncias e as situações, parecendo relevar não tanto os princípios, mas de preferência o interesse

Sobre a crise de 1245 e suas causas ver José Mattoso, Portugal Medieval, 1985, pp. 57-75, ou ainda do mesmo autor «A crise de 1245", Revista de História das Ideias, 6, Coimbra, 1984, pp. 7-23. Ainda quanto à data e à ausência para Castela, cf. Maria Alegria F. Marques, ob. cit., p. 197, n. 144.

(44) Sobre esta questão veja-se Alexandre Herculano, ob. cit., pp. 495-523 e nota XXVIII no fim do vol. II pp. 640-645; ver nota crítica de José Mattoso no mesmo vol. pp. 657-658 e sobretudo o interessante capítulo «Ourém e D. Mécia Lopes de Harow, na obra deste mesmo autor A Nobreza Medieval Portuguesa - A família e o poder, Lisboa, 1981, pp. 279-283. 
e a satisfação das suas ambições. Neste contexto não deixa de ser curioso que o Arcebispo de Braga D. João Viegas de Portocarreiro apesar de ter sido da facção do Conde de Bolonha, contemplou, entre outros legados da sua imensa fortuna, o próprio Deão Fernando Joanes, seu parente e testamenteiro $\left({ }^{45}\right)$.

E que razões ou méritos levaram o cardeal Octaviano Ubaldini, interventor em tantos assuntos referentes à Península Ibérica, a nomear como seu capelão bracarense, Fernão Joanes, precisamente em 1245 , ano em que se celebrou o Concílio de Leão e no fim do qual foi deposto o próprio rei de Portugal, D. Sancho II? Problemas relacionados com o Concílio? Missão em nome de Fernando III, de Castela? Assuntos pessoais? Ou a grande questão referente à deposição de D. Sancho II?

Fernão Joanes, não era um personagem comum ou vulgar no xadrez político de então. $\mathrm{O}$ dinamismo e o movimento que também lhe imprimiu necessita e merece um maior e mais demorado aprofundamento.

\section{A celebração da morte na vida: o testamento}

Como todo o bom homem medievo, em geral, também Fernão Joanes teve tempo de pensar na morte, antes de morrer. E preocupou-se em organizar, enquanto vivia, toda a comemoração que desejava, para além desse último momento.

O seu testamento parece-nos constituir uma peça documental de relevante importância, tanto em ordem a um conhecimento mais completo da sua personalidade, como até, no âmbito da questão que temos vindo a abordar, isto é, das suas relações com Castela.

Não é propriamente pelo conteúdo ou pelo facto de ter sido redigido no reino vizinho, na cidade de Burgos, mas é toda a solenidade da celebração ou um certo espectáculo que o envolve que é, já em si, bastante significativo.

A começar pela categoria das pessoas que testemunharam o acto, algumas delas, até, intimamente relacionadas com Afonso X, como é a presença dos próprios médicos do monarca castelhano e outros personagens. E nisto, é bem expressivo o texto: Presentibus Alfonso Martini et magistro Stephano fisicis domini Regis Castelle et domno Petro Egidii Capellano eiusdem et Fratre Petro et Fratre Egidio de Ordine Fratrum Praedicatorum (46).

(45) Cf. Livro $1 .^{\circ}$ dos Testamentos, n. ${ }^{\circ} 35,41$ e 42 do Arquivo Distrital de Braga; José Augusto Ferreira, Fastos Episcopaes da Igreja Primacial de Braga, Tomo II, Ed. da Mitra Bracarense, 1930, p. 48.

(46) A.D.B. - Livro $1 .{ }^{\circ}$ dos Testamentos do Cabido, n. ${ }^{\circ} 24$, fl. 14. 
Para além desta participação ressalta igualmente de toda a escritura testamentária que o deão é um homem dotado de certos haveres e poder. Por isso determina que o seu corpo seja sepultado na Igreja Bracarense, na sepultura que ele próprio aí mandou construir e que sejam levantadas duas capelas, uma em honra da sempre Virgem Maria, outra em honra de $\mathrm{S}$. Clemente, que parecem ser as grandes figuras de santos da sua devoção. Ficava, assim, marcada e perpetuada, a sua memória $\left({ }^{47}\right)$.

Mas Fernão Joanes, perante o mistério da morte, deixa transparecer, claramente, a sua visão teocêntrica da vida. Cuida, deste modo, que o seu corpo desça dignamente à sepultura, mas posteriormente não menos se preocupa com a alma a fim de que esta suba até Deus. Daí a sua vontade expressa de igualmente ser lembrado através dos tempos na celebração: Item volo quod perpetuo in praedictis capellis duo celebrent capellani pro anima mea ( $\left.{ }^{48}\right)$. Estipula que cada um dos dois capelães celebrantes seja contemplado com vinte morabitinos e com trinta os cónegos da Igreja bracarense que participarem nos aniversários da sua morte ${ }^{(49)}$. E manda que assim se proceda, tendo em conta os rendimentos da sua quintã da Parada; dos casais que aí herdou dos seus antepassados, das herdades que comprou, quer nessa região, como em Louredo; das casas que possuía em Braga e das vinhas e propriedades que comprou em Sepedelos $\left({ }^{50}\right)$.

Para tanto, institui, como legítimo herdeiro de todas estas possessões, o seu sobrinho Martim Peres, devendo depois da morte (e esta é outra particularidade também interessante), passarem tais bens para o clérigo que no critério do referido testamenteiro seja mais apto e descenda em linha recta dos seus próprios pais ( $\left.{ }^{51}\right)$.

Porém, preocupando-se novamente com os sufrágios contínuos pela sua alma, volta a determinar que sejam distribuídas várias importâncias em morabitinos aos Cónegos bracarenses, expressando possivelmente toda a sua motivação: Et volo quod fiat commemoratio pro anima mea eodem die et etiam singulis kalendis et hoc mando fieri per superdictas hereditates (52). E acrescenta, igualmente, como ordem, o que não deixa de ter algo de espirituoso que no dia do aniversário da

(47) Ibidem, fl. 13: «Volo primam quod corpus meum sepeliatur in ecclesia Bracarensi in sepultura quam ibi construere mandavi et volo quod construantur ibi due capelle: una in honore Beatae Mariae semper Virginis et altera in honore Beati Clementis".

(48) Ibidem, fl. 13.

(49) Ibidem, fls. 13 e $13 \mathrm{v}$.

(so) Ibidem, fl. 13v.

(51) Ibidem, fl. 13v.

(52) Ibidem, fl. 13v. 
sua morte seja dado aos cónegos um sestário de vinho, das suas vinhas de Cepedelos, para que o bebam depois das vésperas (53).

Estabelece, seguidamente, certas disposições sobre as herdades que comprou em Briteiros ao cavaleiro João Peres, filho de Pero Soares e à quintã de Volnaria, lembrando ainda no testamento alguns dos seus sobrinhos cuja referência nos merece uma atenção particular (54).

Neste ponto, julgamos dever salientar a exclusão da herança dos filhos de Margarida Peres de Portocarreiro e do marido Pedro Eanes de Vasconcelos, filho de João Pires de Vasconcelos, como consta do próprio texto do testamento e que é do seguinte teor: Ad predictam autem sucessionem nolo quod veniat soboles Margarite petri consoprine mee et Petri Johannis de Vasconcellos et si forte dicta Margarita sobolem ex alio viro susceperit volo quod veniat ad dictam successionem..." (55).

Luís Gonzaga de Azevedo, referindo-se a este facto e depois de transcrever esta mesma passagem testamentária, diz que Aires Anes de Freitas devia ser um afonsista e que foi morto por João Pires de Vasconcelos a quem o deão de Braga, Fernando Joanes de Portocarreiro, era mui oposto, ainda que ele veio a casar com uma sua sobrinha, Margarida Peres (56). Mas pelo texto acima referido, quem casou com a referida sobrinha do deão bracarense foi Pedro Eanes de Vasconcelos filho de João Pires de Vasconcelos, o Tenreiro, sobrinho do Arcebispo D. Estevão Soares, o que também se confirma pelo Livro de Linhagens do Conde D. Pedro conforme se pode ver no quadro seguinte $\left({ }^{57}\right)$.

Daí que a oposição deveria ser dirigida ao filho e não ao pai João Pires de Vasconcelos, o Tenreiro. E porque motivo uma tal oposição? Pelo facto do pai matar o afonsista Aires Anes de Freitas? Não transparece com clareza. É possível, portanto, que existisse um outro mo-

(53) Ibidem, fl. 13v: «et mando eisdem canonicis in die anniversarii mei unum sestarium vini per supradictas vineas de Sepedelos, quod bibant post vesperos". Cf. Peter Linehan, ob. cit., p. 228 , n. 40.

(54) Ibidem, fl. 13v.

(55) Ibidem, fl. 13v. Esta nova leitura deve-se à valiosa ajuda do Prof. Doutor José Geraldes Freire, a quem muito reconhecidamente agradecemos, assim como a revisão das restantes passagens do testamento.

(56) Cf. Luiz Gonzaga de Azevedo, História de Portugal, «Biblion», Lisboa, 1944, p. 156. O facto é referido também pelo Livro de Linhagens do Conde D. Pedro, Ed. crítica de José Mattoso, vol. II/1, Lisboa, 1980, 36E9-10, pp. 407-408. Descreve que Gil Martins, filho de Martim Pais Ribeiro, foi morto por Aires Anes de Freitas e que deste foram tomar vingança no mosteiro de Fonte Arcada, assassinando-o, João Pires de Vasconcelos e seu primo Pedro Anes Alvelo.

(57) Cf. Livro de Linhagens do Conde D. Pedro, ob. cit., 36E9-10, p. 407-409. Livro Velho de Linhagens, Ed. por J. Piel e J. Mattoso, vol. I, Lisboa, 1980, IBG9-10, p. 43; LD4Z7, p. 98; LD9Q6-7, p. 135; LD6AA9, p. 114; LD9AQ7, p. 140. 


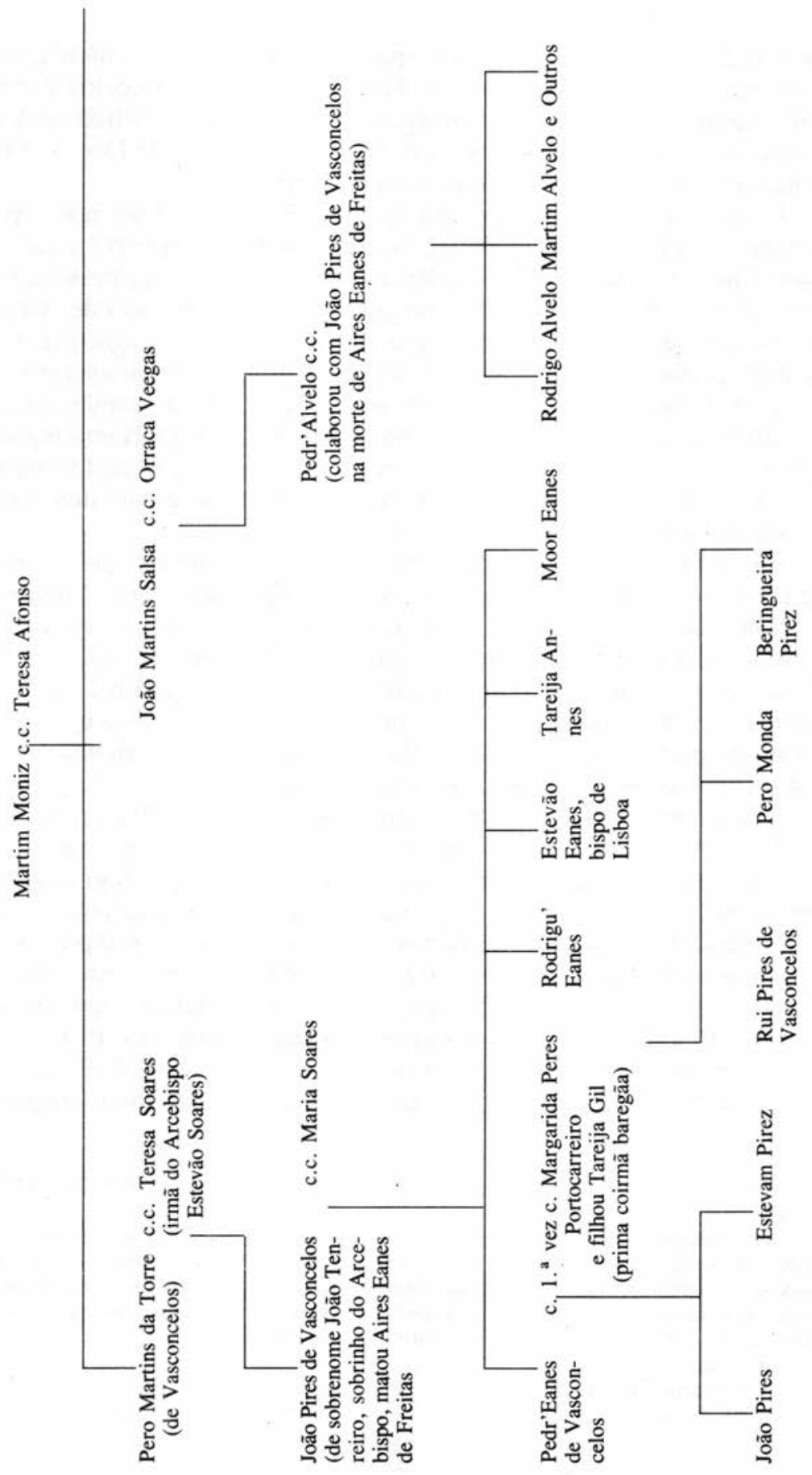


tivo. O Livro de Linhagens do Conde D. Pedro não nos elucida, mas acrescenta: «E filhou despois este Pedr'Eanes de Vasconcelos Tareija Gil, sua prima coirmãa por barregãa, e fez em ela Rui Pirez de Vasconcelos e Pero Monda, que dizem que foi seposo (?) do Demo, e Beringueira Pirez» (58). Será esta uma das razões?

Um outro passo digno de destaque do testamento deste nosso personagem, descendente da ilustre família dos Portocarreiros e que de algum modo pode também ajudar a compreender a sua presença na corte de Castela e talvez o motivo porque era mui privado de Afonso $\mathrm{X}$, é o que se refere à sua mais que provável formação jurídica. Porquanto, deixa expressamente, a Martim Peres, vários manuscritos das obras de Direito Canónico e Civil, pelas quais revela grande apreço, a avaliar pelas condições que faz acompanhar tão importante legado, pois estabelece que quem lhe suceder preste uma caução de 150 morabitinos velhos pelo Decreto de Graciano e 100 por cada um dos outros livros de Direito Canónico e Civil (59).

Faz ainda menção no documento de outros sobrinhos, que são também contemplados com uma determinada importância em libras, mas o critério que segue relativamente a estes não é uniforme. Assim, para João Peres, Fernando Peres, Gonçalo Peres deixa a cada um 500 libras. Mas a João Lourenço, Pedro Lourenço e Martim Lourenço, manda entregar 300 libras a cada um $\left(^{60}\right)$. Não esquece os que o serviram de perto a quem destina 500 morabitinos e recomenda ao seu testamenteiro que em tudo siga o conselho do arcediago de $\mathrm{Braga}, \mathrm{Ge}-$ raldo, a quem deve dar cem morabitinos para a compra duma mula (61).

Mas há um outro gesto que merece igualmente ser evocado, não só pelo que revela de sensibilidade, mas sobretudo por não esquecer um grupo de pessoas, que, se não eram tomadas propriamente como marginais, apareciam, pelo menos, como indesejáveis e repugnantes à própria sociedade: os leprosos. O deão lembra-se dessa gente e manda que lhe sejam dados 10 morabitinos para uma pitança: Item mando leprosis Bracarensis. X. morabitinos ad unam pitantiam (62).

É verdade que esta atitude não é insólita. Quase que obedece a um certo ritual. O seu primo, o Arcebispo de Braga, D. João Viegas de

(58) Livro de Linhagens do Conde D. Pedro, ob. cit., 36E10, p. 409. Cf. LD9Q7, p. 140 .

(59) Ibidem, fl. 13v: Item mando dicto Martino Petri libros meos omnes iuris canonici et civilis. Post mortem uero eius remaneant cum dicta successione ita tamen quod qui successerit post eum prestet caucionem de non vendendis pignorandis uel alienandis ita uidelicet pro Decreto prestet caucionem in CL morabitinos ueteres et pro omnibus aliis iuris canonici et civilis in $\mathrm{C}$ pro quolibet libro.

(60) Ibidem, fl. 13v.

(61) Ibidem, fl. 13v

(62) Ibidem, fl. 13v. 
Portocarreiro, já antes, e também no seu testamento, tinha ordenado que muitas das suas roupas de linho e de lã, do próprio vestuário, fossem vendidas e o seu produto distribuído pelos pobres e leprosos, confinados pelos limites do rei Douro até ao Lima (63). Como, aliás, assim procederam alguns dos nossos primeiros reis, D. Sancho I lembra os de Coimbra (64). D. Afonso II não especifica a sua origem, mas também não os esquece (65). E D. Afonso III deixa mil libras a todos os leprosos do reino $(66)$.

Tratava-se, é verdade, de um restrito número de cidadãos, mas que impressionava e pesava como chaga sobre a sociedade medieval, a que esta era sensível, a ponto de lhe provocar estes gestos de digna comiseração.

Os Frades Menores e os Frades Pregadores de Guimarães também são recordados e objecto duma palavra de estima. A cada uma destas ordens determina que sejam entregues 50 libras para a ajuda da construção dos seus respectivos mosteiros $\left({ }^{67}\right)$. E termina por referir ainda outros servidores, assim como, mais uma vez, os cónegos da Igreja de Braga, a quem manda entregar 100 morabitinos no dia da sua sepultura (68).

Por fim, okdena não só que o seu testamento seja registado no Livro Capitular dos Testamentos, mas também que seja lido todos os anos no próprio Cabido ( $\left.{ }^{69}\right)$.

(63) «Item mando vero vestes meas de lino et de lana de corpore meo de lecto quibus utor et cepi uti et teneo in peciis et mapas et mantela pro anima mea distribuenda pauperibus et leprosis de citra Dorium usque ad Limiam distribuenda posteaque fuerint vendita». A.D.B. - Livro $1 .^{\circ}$ dos Testamentos, n. ${ }^{\circ} 35$.

(64) Cf. Rui de Azevedo, Avelino de Jesus Costa, Marcelino Rodrigues Pereira, Documentos de D. Sancho I (1174-1211), vol. I, Universidade de Coimbra, 1979, p. 297 , n. 194.

(65) Cf. Monarquia Lusitana. Parte IV, Lisboa, Imprensa Nacional-Casa da Moeda, 1974, pp. 271 e [143], para o texto latino e tradução.

(66) Cf. Monarquia Lusitana, cit., pp. 285 e [179], para o texto latim e português. Ainda sobre esta temática veja-se Maria Teresa Nobre Veloso, A morte nos testamentos dos Clérigos Bracarenses do século XIII, Coimbra, 1988 e Maria Helena da Cruz Coelho, «Um testamento redigido em Coimbra no tempo da peste negra», in Homens, Espaços e Poderes - Séculos XI-XVI - Notas do Viver Social, Livros Horizonte, 1990 e da mesma autora «A pobreza e a assistência aos pobres na Península Ibérica durante a Idade Média» - Actas das 1. as Jornadas Luso-Espanholas de História Medieval, Tomo I, Lisboa, 1973, pp. 231-258.

(67) «...Item mando fratribus minoribus et predicatoribus L.L. libras. ad monasteria construenda et rogo quod si in aliquo eis erravi parcant mihi..." Livro $1 .^{\circ}$ dos Testamentos do Cabido, n. ${ }^{\circ} 24$, fl. 13v. Cf. Peter Linehan, ob. cit., p. 228 e n. 40.

(68) Ibidem, fl. 13v: «...Item mando canonicis Bracarensis. C. morabitinos veteres in die sepulture mee».

(69) Ibidem, fl. 13v: «Et volo quod testamentum istud scribatur inter alia testamenta in libro Capituli et singulis annis legatur in Capitulo». 
A sua morte deve situar-se entre 10 de Novembro de 1272 (data do seu testamento) $\left({ }^{70}\right)$ e as Letras Dilectum Filium de Inocêncio $V$, de 31 de Março de 1276, enviadas a Pedro Hispano, então cardeal bispo de Tusculum (e depois papa João XXI). Porque por estas Letras o pontífice encarregou o cardeal português de reaver os bens deixados por Fernão Joanes que tinha morrido junto de Santo Saturnino quando seguia a caminho ou já no regresso da Cúria Pontifícia (curiam nostram sequentem apud Sanctum Saturninum), bens esses que Martim Peres, João Martins e outros se tinham apropriado, com prejuízo da Câmara Apostólica. Por isso a 16 de Maio do mesmo ano o cardeal escreveu ao arcebispo de Braga, D. Ordonho, ordenando-lhe que obrigasse os referidos familiares do deão a restituir os bens que dele herdaram ao delegado da Cúria Pontifícia, D. Geraldo, arcediago do Couto, por se entender pertencerem à Santa Sé, tendo em conta a observância dos antigos costumes sobre os bens dos que morriam em tais circunstâncias, uma vez que constava ter morrido sem testamento. pront audivimus intestatum non sine camerae nostrae ad quam taliter decedentium bona de antiqua et observata consuetudine aspectare noscuntur preiudicio $\left({ }^{71}\right)$.

Mas é possível que Miguel Peres e Fernão Joanes de Portocarreiro não sejam os únicos portugueses referidos no presente diploma régio.

A questão final que levantamos é a propósito de Pedro Moniz, cónego de Leão (sic), também mencionado no mesmo documento do monarca castelhano e que, desde logo, igualmente, nos despertou a atenção, pelo que, de imediato, nos interrogámos, baseados em argumentos que nos parecem, de certo modo, consistentes, se não seria precisamente o português Pedro Moniz, cónego de Lamego. Não pelo facto de vir mencionado no texto com o mesmo nome e entre os dois referidos portugueses, facto que, embora insignificante, não deixa de tornar a questão mais lógica, mas sobretudo pelos importantes dados que conhecemos também a seu respeito e que nos levam a suscitar a questão $\left.{ }^{(72}\right)$. Tanto mais que na documentação de Fernando III, durante o período de 1217 a 1253, não encontrámos, com excepção do presente diploma

(70) Ibidem, fls. 13v-14: «Actum Burgis apud beatum Felicem quarto Idus Novembris Era $\mathrm{M}^{\text {a }} \mathrm{CC}^{\text {a }}$ decima».

(71) Ver José Antunes, "O percurso e o pensamento político de Pedro Hispano...", in $o b$. cit., p. 149.

(72) Trata-se apenas de uma hipótese que, embora nos pareça plausível, preferimos destacá-la para a parte final deste trabalho e dar-lhe, oportunamente, um maior estudo e desenvolvimento. O nome de Pedro Moniz, como é fácil verificar, no presente documento, encontra-se entre os dois referidos portugueses, do seguinte modo: e Ferrand iohannes de porto carrero e Pedro Munniz calonigo de leon e Miguel Pz̃ calonigo de Lamego, o que só por si insinua já o levantamento da questão. 
de 1243, qualquer personagem denominado Pedro Moniz, cónego de Leão (73). Encontramos, sim, na documentação portuguesa, um $\mathrm{Pe}$ dro Moniz, mas seguramente como cónego de Lamego ( $\left.{ }^{74}\right)$.

Existiu, de facto, um célebre canonista, que foi deão de Leão, e depois bispo de Santiago de Compostela de 1205 a 1223, ano em que morreu, também chamado Pedro Moniz e que Lucas de Tuy qualificou de vir literatus admodum et honestus. Sustentou, até, com S. Martín de Leão, uma disputa sobre Sagrada Escritura, da qual saiu vencido, pelo Santo, que era eminente, ao que parece, em cultura exegética. Mas, como já referimos, morreu em 1223, isto é, vinte anos antes do diplona de 1243. E desde esta data não se conhece outro com o mesmo nome (75).

Equívoco, então, do copista, lendo Leão, em vez de Lamego, por confusão com o célebre canonista leonês que morrera em 1223? Ou trata-se mesmo do português Pedro Moniz, porventura até cónego de Leão, à semelhança de outros portugueses que foram cónegos em dioceses dos reinos vizinhos e vice-versa? E, também, uma possibilidade ${ }^{(76)}$.

Mas quem era este Pedro Moniz, cónego de Lamego, para merecer ser nomeado, porventura, para a Junta Universitária de Justiça, e ser identificado, como hipótese, com Pedro Moniz, cónego de Leão, de que fala o documento de 1243 ?

Era, certamente, também um jurista. Porquanto, abrindo o seu testamento, celebrado em 19 de Junho de 1262, ressalta logo das primei-

(73) Referimo-nos à obra de Julio Gonzalez, cit., sobretudo o II e III volumes Reinado y diplomas de Fernando III.

(74) Para já temos o seu testamento que se encontra no Arquivo Distrital de Braga, Livro dos Testamentos, vol. I, fls. $1 \mathrm{n} .^{\circ} 2$; foi publicado por Mário Júlio de Almeida Costa, Para a Cultura Jurídica Medieva em Portugal, Coimbra, 1959 (Separata do Boletim da Faculdade de Direito, vol. XXXV), pp. 14-16 e quase na totalidade por Isaías da Rosa Pereira, «Livros de Direito na Idade Média», Lusitania Sacra, Lisboa, 1964/1966, Tomo VII, pp. 25-26 e posteriormente por Artur Moreira de Sá, Primórdios da Cultura Portuguesa, I, Lisboa, 1966, pp. 94-96, n. ${ }^{\circ} 61$. Veja-se ainda a bula Tue probitatis meritis, de Alexandre IV sobre a concessão a Pedro Moniz da prebenda do mestre-escolado de Braga, para além de outras informações, em Ildefonso Rodrigues Lama, ob. cit., pp. 232, n. ${ }^{\circ} 243$.

(75) Sobre este canonista e a referida disputa, ver, por exemplo, Vicente Beltrán de Heredia, Cartulario de la Universidad de Salamanca (1218-1600), I, Universidad de Salamanca, 1970, pp. 45-46.

(76) Veja-se, a título de exemplo, o caso bastante elucidativo do seu contemporâneo, mestre Bernardo, deão de Lisboa, arcediago de Leão, beneficiado de Compostela e ainda cónego de Tui e Palência, conforme se prova pelas bulas Illos non inmerito de Alexandre IV, datadas de 31 de Março e de 1 de Abril de 1255 (Cf. Ildefonso Rodriguez de Lama, ob. cit., pp. 65-66, n. ${ }^{\circ} 41$ e 42) e as bulas Tuis inclinati precibus, de 13 de Fevereiro de 1253 e ainda a Devotionis tue probata, de 21 de Julho de 1254 (Cf. Augusto Quintana Prieto, ob cit., p. 751, n. ${ }^{\circ} 854$ e 869, n. ${ }^{\circ} 991$ e Maria Alegria F. Marques, $o b$ cit., pp. 151 e 159). 
ras expressões do texto a preocupação em dar um destino digno ou em salvaguardar o que mais estimava e que constituía, por certo, o centro das suas atenções e inclinações: os seus livros de Direito. Assim, o seu Código de Justiniano e o Esforçado lega-os a D. Martinho, Arcebispo de Braga, intuitu personae (77). O Digesto Velho à igreja de Sacavém para que seja vendido e com o produto da transacção possam ser compradas possessões para a referida Igreja $\left({ }^{78}\right)$. O Digesto Novo ao Cabido bracarense ( $\left.{ }^{79}\right)$. As suas Decretais serão legadas ao Cabido de Lamego, cuja venda, juntamente com os frutos das prebendas anuais, serão destinados para suportar as despesas com a celebração do aniversário da sua morte ${ }^{\left({ }^{80}\right)}$. O mesmo se diga do seu Volumen parvum que determina seja vendido por intermédio de Domingos $\mathrm{Pi}$ res, chantre de Guimarães e de Estêvão João, cónego bracarense, para que com o seu produto se realizem as exéquias pela sua alma (81).

Mas há um outro facto referido que não pode deixar de estar relacionado com a sua cultura jurídica. E a sua presença na cidade universitária de Bolonha, onde fez o seu próprio testamento e possuía alguns bens que, conforme refere o texto, destinou aos seus irmãos Ricardina, cuja distribuição ficaria ao arbítrio dos seus fideicomissários, o chantre de Guimarães, Domingos Pedro e Estêvão João ( ${ }^{82}$ ). Além disso, os personagens que evoca ou que o rodeiam são homens de grande envergadura intelectual. O Arcebispo de Braga, D. Martinho Geraldes, é o seu herdeiro e testamenteiro ( $\left.{ }^{83}\right)$. Estão presentes ao acto testamentário doutores em Leis, como D. Francisco e D. Cerueyro e membros os alto clero, como Domingos Pedro, chantre vimaranense, Estêvão João, cónego de Braga, João Egídio, cónego de Guimarães e Sancerto da diocese de Sagrim (?) (84).

As actas da escritura pública tiveram lugar na cidade de Bolonha,

(77) «In primis lego domino Martino archiepiscopo bracarensi, intuitu personae, Codicem meum et Inforciatum. Veja-se Isaías da Rosa Pereira, ob cit., p. 25 e notas 98 a 103 bem esclarecedoras sobre os Livros de Direito; cf. Artur Moreira de Sá, ob cit., p. 94 e sobretudo Mário Júlio de Almeida Costa, ob cit., p. 14, cuja leitura do texto seguimos nas transcrições seguintes.

(78) «Lego Digestum vetus ecclesie de Saccavem, ita quod vendatur et de precio emantur possessiones pro supra dicta ecclesia de Saccavem». Ibidem, p. 15.

(79) «Lego Digestum novum capitulo Bracarensi predicto tenore». Ibidem, p. 15.

(80) «Lego capitulo Lamecensi Decretales meas predicto tenore ita quod... fiat anniversarium pro anima mea». Ibidem, p. 15.

(81) «Item de Volumine meo volo quod fiant exsequie mee... volo vendi per dominum Dominicum Petri cantorem Vimaranensem et dominum Stephanum Johannis canonicum... Ibidem, p. 15.

(82) "Alie res mee quas habeo Bononie distribuantur pro arbitrio supradictorum...", Ibidem, p. 15.

(83) «... Martinum Archiepiscopum Bracarensem heredem meum instituo et rogo ut omnia mea legata et relita adimpleat». Ibidem, p. 15.

(84) Ibidem, pp. 15-16. 
na presença do notário, dotado de autoridade imperial, Jacobinus Michelis Meroline e ainda de eclesiásticos altamente qualificados (alguns, até, de Castela, o que também não deixa de ser significativo), como D. Pedro Garcia, arcediago de Saragoça, mestre Gonçalo, arcediago Modionense, D. Pedro Martín, cónego Auriense, D. João, cónego de Palencia, D. Garcia Pedro, cónego de Zamora, D. Bernardo Arias, cónego de Santiago de Compostela, D. Barneca, cónego de Leão, D. Domingos Estêvão, cónego de Guimarães, João Martins e outros já acima mencionados $\left({ }^{85}\right)$.

Também a bula Tue probitatis meritis, de Alexandre IV, datada de 7 de Março de 1257, de Latrão, nos oferece importantes elementos biográficos sobre Pedro Moniz. Por este valioso documento somos informados que era reitor da Igreja de Sacavém, da diocese de Lisboa e cónego da Igreja de Lamego, donde também recebia as correspondentes prebendas. Que atendendo às súplicas do beneficiado e do próprio Arcebispo D. Martinho, de quem era familiar, poderia não só suceder no mestre-escolado da Sé bracarense a D. Martinho Geraldes, por este ter sido elevado ao Arcebispado de Braga, mas receber, juntamente com as anteriores, as respectivas prebendas do seu novo cargo (86).

É verdade que alguns destes cargos e funções são, como é óbvio, posteriores à data do documento de 1243 de Fernando III. Porém, não deixam de ser igualmente significativos enquanto só vêm confirmar o valor daquele que possivelmente fez também parte da Junta Universitária de Justiça e que além de cónego de Lamego, foi também reitor da Igreja de Sacavém, mestre-escola da Sé de Braga e porventura estudante e professor de Direito na Universidade de Bolonha.

A confirmar-se uma tal hipótese, seriam, então, portugueses, os três personagens que assim e seguidamente se encontram no texto do privilégio de 1243, nomeados por Fernando III, para a Junta Universitária de Justiça: Ferrand iohannes de porto carrero, Pedro Moniz e Miguel Peres.

Percorrendo os documentos da Chancelaria de Fernando III, publicados na obra de Julio González, Reinado y diplomas de Fernando III ( $\left.{ }^{87}\right)$, os nomes de Miguel Peres, cónego de Lamego e de Fernando

(85) Ibidem, p. 16. Há uma diferença de leitura, entre os autores citados, relativamente a dommni Fernandi Arie canonici Compostellani. Isaías da Rosa Pereira, $o b$. cit., p. 26, lê domni Bernardi Arie canonici Compostellani.

(86) A bula encontra-se transcrita na íntegra em Ildefonso Rodriguez Lama, ob. cit., pp. 158 e n. ${ }^{\circ} 168$.

(87) Cf. Julio Gonzalez, Reinado y diplomas de Fernando III, vol. I Estudio, Cordoba, 1980; vol. II Diplomas (1217-1232), Cordoba, 1983 e vol. III Diplomas (1233-1253), Cordoba, 1986, pp. 261-262. 
Joanes de Portocarreiro, apenas se encontram, assim designados, uma vez, e num único e mesmo documento, isto é, precisamente no documento que trata do célebre privilégio concedido pelo monarca aos Estudos de Salamanca e que vem transcrito no Vol. III, sob o n. ${ }^{\circ} 709$, pp. 261-262. Isto significa que tanto um como outro foram convidados propositadamente para este último acto, o que mais vem reforçar a asserção de que além do cónego de Lamego outro português foi designado para a referida Junta Universitária de Justiça que no caso presente seria Fernando Joanes de Portocarreiro.

No documento o seu nome não vem acompanhado de qualquer título honorífico. Nessa altura, porém, era chantre da Sé de Braga, pois, como vimos, já em 1242 assim era intitulado, precisamente quando disputou ao bispo do Porto a Igreja do Monte Córdova.

Ora o prestígio de ser descendente de família da nobreza portuguesa, a dos Portocarreiros, o poderio de que poderia dispor em homens e em recursos, o facto de fazer parte do Cabido da Sé de Braga e possivelmente a sua formação jurídica, constituía uma razoável credencial para fazer parte da Junta que D. Fernando III, rei de Leão e Castela, nomeou para as suas Escolas de Salamanca.

Além disso, para Afonso X, o rei Sábio, escolher o deão de Braga, Fernando Joanes de Portocarfeiro, como seu notário e procurador, é porque lhe reconhecia verdadeiro valor e a formação jurídica necessária para o exercício de um cargo verdadeiramente peculiar. $\mathrm{O}$ que aliás está em harmonia com o facto de possuir os Livros de Direito Canónico e Civil que lega em testamento, feito em Burgos, a seu sobrinho Martim Peres ( ${ }^{88}$ ), e que, para o tempo, se considera uma verdadeira riqueza cultural e privilégio de poucos.

E se o monarca castelhano o chamou à sua corte é porque, possivelmente, já há muito o conhecia, isto é, talvez desde o tempo do governo do seu próprio pai a quem sucedeu.

Se Pedro Moniz, perante os argumentos aduzidos, é também português, não obstante aparecer no referido documento de 1243 como cónego de Leão, então a hipótese torna-se verosímil, embora digna de maior aprofundamento. Porém, de tudo o que ficou dito constata-se o facto, cada vez mais evidente, de que entre Portugal e os reinos vizinhos medievos, não existiam grandes barreiras ou fronteiras culturais.

Certamente que as determinações do Concílio III e IV de Latrão, celebrados respectivamente em 1179 e 1215 , constituem o mais notável impulso para a criação e organização das mais antigas Universidades da Europa.

Daí que as Escolas instituídas junto das catedrais e mosteiros e con-

(88) Cf. nota 59 . 
sequentemente um elevado número de homens cultos, tanto do clero secular como regular, alguns deles até mestres de grande prestígio em Universidades estrangeiras, como Paris e Bolonha, jamais se poderão dissociar da preexistência de um ambiente cultural de certo modo forte entre nós.

Mas apraz-nos igualmente registar que Portugal também não esteve totalmente ausente do processo histórico da fundação da vizinha Universidade Salmanticense, a qual, tanto na génese dos Estudos Gerais Portugueses, como no seu devir, teve, sem dúvida, grande repercussão e presença. 